\title{
Suitability of certain strawberry genotypes for breeding of new cultivars tolerant to leaf diseases based on their combining ability
}

\author{
Agnieszka Masny • Sylwester Masny • \\ Edward Żurawicz $\cdot$ Kris Pruski $\cdot$ Wiesław Mądry
}

Received: 7 January 2016/Accepted: 31 March 2016/Published online: 12 April 2016

(C) The Author(s) 2016. This article is published with open access at Springerlink.com

\begin{abstract}
The aim of the study was to estimate the general and specific combining abilities (GCA and SCA) of 13 dessert strawberry cultivars: 'Figaro', 'Salsa', 'Palomar', 'Granda', 'Camarosa', 'Elianny', 'Aromas', 'Diamante', 'Portola', 'Charlotte', 'San Andreas', 'Monterey' and 'Albion' for tolerance to the major leaf diseases strawberry leaf spot (Mycosphaerella fragariae (Tul.) Lindau), leaf scorch (Diplocarpon earliana (Ell. \& Ev.) Wolf) and powdery mildew (Sphaerotheca macularis (Wallr.) U. Braun). The crossing programme was performed in the winter of 2010/2011 in the glasshouse following a half-diallel cross mating design (Griffing's method IV). Progenies of the 78 newly obtained families were
\end{abstract}

\footnotetext{
A. Masny $(\varangle) \cdot$ E. Żurawicz

Department of Breeding of Horticultural Crops, Research Institute of Horticulture, Konstytucji 3 Maja 1/3, 96-100 Skierniewice, Poland

e-mail: Agnieszka.Masny@inhort.pl

S. Masny

Department of Plant Protection, Research Institute of Horticulture, Konstytucji 3 Maja 1/3,

96-100 Skierniewice, Poland

K. Pruski

Department of Plant and Animal Sciences, Dalhousie University, Truro, NS B2N 5E3, Canada

\section{W. Mądry}

Department of Experimental Design and Bioinformatics, Warsaw University of Life Sciences, Nowoursynowska 166, 02-787 Warsaw, Poland
}

evaluated in field conditions (randomized complete block design, 4 replicates, 15 plants per plot). Observations of the severity of plant infection with leaf spot, leaf scorch and powdery mildew were recorded from 2011 to 2013. Statistical analysis of data was performed according to Griffing's fixed model. The most numerous significant and positive GCA effects were estimated for cv.'Salsa' for low plant susceptibility (tolerance) to all three diseases assessed. High GCA effects were also showed for cvs 'Figaro' and 'San Andreas'-for low plant susceptibility to leaf spot and leaf scorch, and for cv.'Diamante'-for low plant susceptibility to leaf spot and powdery mildew. Lower breeding values for the estimated traits were observed with cv.'Camarosa'-for low susceptibility to leaf spot; with cvs 'Palomar' and 'Granda'-for low plant susceptibility to leaf scorch, and with cvs 'Monterey', 'Portola' and 'Charlotte' - for low plant susceptibility to powdery mildew. The lowest GCA effects for low plant susceptibility to the all three leaf diseases tested were observed with cv. 'Albion'. High usefulness for breeding new, resistant varieties has also been observed in the combination 'Aromas' $\times$ 'Elianny', which has significantly negative SCA effects for the susceptibility of plants to both strawberry leaf spot and leaf scorch.

Keywords GCA - SCA - Strawberry leaf spot · Strawberry leaf scorch - Powdery mildew of strawberry 


\section{Introduction}

The strawberry is an important small fruit crop widely grown around the world. However, the vast majority of strawberry fruit production takes place in the northern hemisphere, on continents such as North America (as much as $78 \%-1.4$ million tonnes, mainly in the USA), Europe (1.3 million tonnes, mainly in Spain, Russia, Germany, and Poland) and Asia (800 thousand tonnes, mainly in Japan and Korea) (FAOSTAT 2014; data for the year 2012). Due to differences in climate and soil conditions between the different continents, there are different problems in cultivation of strawberries in each of these areas, including infection of plants with fungal and/or bacterial diseases that are of major economic importance.

In North America, strawberry plants are prone to infection by a number of pathogens including Diplocarpon earliana (Ell. \& Ev.) Wolf causing leaf scorch, Mycosphaerella fragariae (Tul.) Lindau (anamorph Ramularia tulasnei Sacc., leaf spot), Dendrophoma obscurans (Ell. \& Ev.) Anderson (leaf blight), Sphaerotheca macularis (Wallr.) U. Braun (syn. Podosphaera aphanis (Wallr.) U. Braun \& S. Takam., powdery mildew), Gnomonia fructicola (Arnaud) Fall (leaf blotch), Colletotrichum acutatum Simmonds (strawberry black spot) and Phytophthora fragariae Hickman (red stele) (Averre et al. 2002).

In Asia, strawberry plants are usually affected by the powdery mildew of strawberry, verticillium wilt (Verticillium dahliae Kleb.) and Phytophthora root rot (Phytophthora sp.), and in recent years also by Fusarium wilt (Fusarium oxysporum f. sp. fragariae) (Maas 2014).

In Europe, strawberry plants are mainly infected by fungi that cause root diseases, such as: Phytophthora cactorum (Leb. \& Cohn.) Schroet, P. fragariae, $C$. acutatum and $V$. dahliae, and also the fungi $M$. fragariae, D. earliana, and S. macularis and the bacteria Xantomonas fragariae Kennedy \& King (strawberry angular leaf spot) affecting the leaves and other aboveground organs. In countries with a warm Mediterranean climate like Egypt, France, Spain, Israel and India, a serious threat is posed by Macrophomina phaseolina (Tassi) Goidanich (responsible for charcoal rot), affecting the leaves, runners, roots and the crown of strawberry plants (Maas 2014). Of the mentioned above leaf pathogens only $M$. fragariae, D. earliana, and S. macularis are common in Poland. Diseases caused by these pathogenes have been observed since beginning of the second half of the 20th century, when the commercial strawberry cultivation has begun in Poland.

Chemical control of many of these diseases is expensive and often ineffective due to the limited range of available plant protection products. Moreover, in accordance with the general principles of integrated plant protection set out in Annex III to Directive 2009/128/WE, priority in the control of harmful organisms is currently given to non-chemical methods. One such method is the cultivation of cultivars that are low susceptible or resistant to economically important pathogens. Developing new cultivars that would combine good productivity, high fruit quality (size, shape, colour, glossiness, firmness, flavour, shelf-life, and the presence of health-promoting compounds) and plant tolerance to diseases is the goal of the ongoing breeding work (Simpson 2014).

Knowledge of the breeding value (general and specific combining ability) of the parental forms used in crossbreeding programmes as well as the fundamental knowledge on the genetic determinants of the intensity of quantitative traits at the population level (Muszyński et al. 2000) accelerates and increases the likelihood of achieving the intended purpose. In crossbreeding, the use of parental forms with high general combining ability (GCA) effects (a measure of additive effects of genes-Griffing 1956a, b) for the desired functional traits allows us to expect, with high probability, that their offspring will be characterized by high values of these traits (Vieira et al. 2009). Conversely, knowledge of the specific combining ability (SCA) of a pair of parental forms (which is a genetic interaction of both parents as a result of nonadditive gene action (dominance and epistasis), showing in their offspring - Griffing 1956a, b), in respect of the trait under consideration, allows for an examination of the differences between the value of the revealed trait and the value expected on the basis of the sum of GCA effects for those parental forms (Bestfleisch et al. 2014). The quotient of the mean square deviations for GCA and SCA $\left(\mathrm{S}_{\mathrm{GCA}}^{2} / \mathrm{S}_{\mathrm{SCA}}^{2}\right)$ provides for the determination of which genetic effects (additive or non-additive) have a predominant share in determining a given trait in the tested progeny (Fort and Shaw 2000).

The aim of the study was to estimate the general and specific combining ability of 13 dessert strawberry 
cultivars for the susceptibility of plants to the leaf diseases leaf spot, scorch and powdery mildew, and to determine the contribution of additive and non-additive effects in the genetic determination of these traits present within the gene pool under consideration.

\section{Materials and methods}

\section{Plant material}

The study was conducted at the Research Institute of Horticulture in Skierniewice, Poland, in 2011-2013. The experimental plants were $F_{1}$ seedlings belonging to 78 hybrid families derived from crosses in a complete diallel design (fixed model, Griffing's method IV; Griffing 1956b) of 13 dessert strawberry cultivars ('Figaro', 'Salsa', 'Palomar', 'Granda', 'Camarosa', 'Elianny', 'Aromas', 'Diamante', 'Portola', 'Charlotte', 'San Andreas', 'Monterey' and 'Albion'). Descriptions of all these parental genotypes are available (Faedi et al. 2009; Finn 1999; Masny and Żurawicz 2009, 2010, 2013). The detailed information regarding the plant disease susceptibility of the strawberry cultivars based on these references and results of trials performed at the Research Institute of Horticulture in Skierniewice, Poland, is presented in Table 1.
Glasshouse and field experiments

The cross-breeding programme was conducted in a glasshouse over the period from February 23 to March 29, 2011. Plants used in experiments were grown in plastic pots having a diameter and volume of $18 \mathrm{~cm}$ and 3.3 L respectively. On May 9, 2011, the obtained seeds were sown into the pots filled with a 3:1 mixture of peat substrate and sand, and placed on growing benches in a glasshouse $\left(22 / 18^{\circ} \mathrm{C}\right.$ day/night temperature, $16 \mathrm{~h}$ photoperiod). Germinating seedlings were pricked out into multi-cell trays $(54$ cells, $7 \times 7 \mathrm{~cm}$ each) over the period from May 26 to June 7. They were then grown under the same glasshouse conditions.

The field experiment was established with a total of 4680 seedlings randomly selected from a larger number of hybrids belonging to 78 hybrid families. Each hybrid family was represented by 60 plants (seedlings), which were different genotypes. The experiment was planted on July 11-12, 2011 in a randomized block design with four replications of 15 plants randomly placed in the plot, and spaced at $0.4 \times 1.1 \mathrm{~m}$. The experiment was established on mineral soil and a fawn floor of light clay with a $\mathrm{pH}$ of 6.5-6.8 and performed in the open field conditions. White mustard (Sinapis alba) was cultivated in four seasons as a fore crop. However, the soil was not
Table 1 Leaf disease susceptibility of 13 dessert strawberry cultivars used for the crosses in a complete diallel design

a Means no visible symptoms of the disease

\begin{tabular}{|c|c|c|c|}
\hline \multirow[t]{2}{*}{ Cultivar } & \multicolumn{3}{|l|}{ Plant susceptibility to } \\
\hline & Strawberry leaf spot & Leaf scorch & Powdery mildew \\
\hline Figaro & Resistant $^{\mathrm{a}}$ & Resistant $^{\mathrm{a}}$ & Resistant $^{\mathrm{a}}$ \\
\hline Salsa & Resistant $^{\mathrm{a}}$ & Resistant $^{\mathrm{a}}$ & Resistant $^{\mathrm{a}}$ \\
\hline Palomar & Resistant $^{\mathrm{a}}$ & Resistant $^{\mathrm{a}}$ & Resistant $^{\mathrm{a}}$ \\
\hline Granda & Resistant $^{\mathrm{a}}$ & Moderately susceptible & Low susceptible \\
\hline Camarosa & Resistant $^{\mathrm{a}}$ & Low susceptible & Low susceptible \\
\hline Elianny & Resistant $^{\mathrm{a}}$ & Low susceptible & Moderately susceptible \\
\hline Aromas & Moderately susceptible & Moderately susceptible & Low susceptible \\
\hline Diamante & Low susceptible & Moderately susceptible & Resistant $^{\mathrm{a}}$ \\
\hline Portola & Low susceptible & Moderately susceptible & Moderately susceptible \\
\hline Charlotte & Resistant $^{\mathrm{a}}$ & Resistant $^{\mathrm{a}}$ & Low susceptible \\
\hline San Andreas & Low susceptible & Low susceptible & Low susceptible \\
\hline Monterey & Resistant $^{\mathrm{a}}$ & Moderately susceptible & Resistant $^{\mathrm{a}}$ \\
\hline Albion & Resistant $^{\mathrm{a}}$ & Moderately susceptible & Resistant $^{\mathrm{a}}$ \\
\hline
\end{tabular}


fumigated prior to establishment of the experiment. Although the plots were maintained according to the standard recommendations for commercial plantations, no chemical protection was used against leaf diseases (leaf spot, leaf scorch, powdery mildew) after the harvest that was completed by the end of June. During dry periods the plants were watered by a IRTEC 40FBT/130 self-propelled sprinkler (IRTEC S.P.A., Castelvetro, Italy) at least once a week.

\section{Weather conditions}

Over the duration of the experiment in 2011-2013, the weather conditions (including air temperature at a height of $2 \mathrm{~m}$ and the amount of precipitation) were recorded using an iMetos meteorological station (located about $1 \mathrm{~km}$ away from the field where the experiment was conducted). On the basis of these measurements, mean daily and weekly temperatures, and total precipitation were calculated.

\section{Traits studied}

All the seedlings (4680 genotypes in total) were individually assessed in terms of the severity of leaf spot, leaf scorch, and the powdery mildew of strawberry only one time-in the second half of September of the years 2011-2013. Ranking scale 0-5 was used for the leaf spot and the leaf scorch: 0 indicated healthy plants; 1 - up to $1 \%$ of leaf surface covered with spots; 2-from 1.1-5 \% of leaf surface covered with spots; 3-from 5.1-20\% of leaf surface covered with spots; 4-from 20.1-50\% of leaf surface covered with spots; 5 -more than $50 \%$ of leaf surface covered with spots. For powdery mildew, 0 - determined healthy plants; 1 -traces of leaf infection (up to $10 \%$ of leaf surface with symptoms of powdery mildew); 2-clearly evident infection on the leaves (10.1-20\% leaf surface with symptoms of powdery mildew); 3 -leaves beginning to curl (20.1-50\% leaf surface with symptoms of powdery mildew); 4-leaves curling up (50.1-80\% leaf surface with symptoms of powdery mildew); 5infection of the whole plant (more than $80 \%$ of damage caused by powdery mildew).

Statistical analysis

A two-stage analysis of both single-year and combined data (across the three test years) was performed for all the evaluated traits (Garretsen and Keuls 1978; Zhang et al. 2005; Möhring and Piepho 2009). In the first stage, the SAS PROC MIXED procedure (SAS Institute 2000) was used to perform the analysis of variance assuming the hybrid families to be a fixed factor, while the blocks were the random factor (Möhring and Piepho 2009).

After finding significant variation for the studied traits among the hybrid families, the second stage involved performing a fixed model-based diallel analysis of variance of family means (calculated across replications) together with estimating GCA and SCA effects as outlined by Griffing (1956b) for single-year data and Zhang et al. (2005) for the combined data from a half-diallel complete mating design with parents treated as a fixed factor (Method IV, Model 1). Further valuable methodological background and justification for these analyses is presented by Baker (1978) and their empirical use for fruit crops is illustrated, for example, by Giménez and Ballington (2002) and Dossett et al. (2008).

The relative importance of GCA and SCA was estimated using the general predicted ratio (GPR) for the traits observed as follows: GCA/ $\mathrm{SCA}=\left(2 \mathrm{MS}_{\mathrm{GCA}}\right) /\left(2 \mathrm{MS}_{\mathrm{GCA}}+\mathrm{MS}_{\mathrm{SCA}}\right) \quad($ Baker 1978). This diallel analysis was conducted using the SAS PROC GLM procedure (SAS Institute 2000). A detailed analysis of the significance of the GCA and SCA effects was made using a simultaneous test procedure based on the Bonferroni inequality (Garretsen and Keuls 1978).

\section{Results}

Weather conditions

The mean daily and weekly temperatures as well as the total precipitation varied considerably during the vegetation period in the different years of the study (Figs. 1, 2).

The highest rainfall $(505 \mathrm{~mm})$ in the period from the beginning of April to the end of October was recorded in the 2011 season. The rainiest month of that year was July; from July 1 to 28 the total rainfall was $157.4 \mathrm{~mm}$. Abundant rainfall was also recorded in the period from April 22 to 28 (43.2 mm), from June 3 to 9 $(65.0 \mathrm{~mm})$, and from August 5 to $11(40.2 \mathrm{~mm})$. By contrast, the months of September and October 2011 


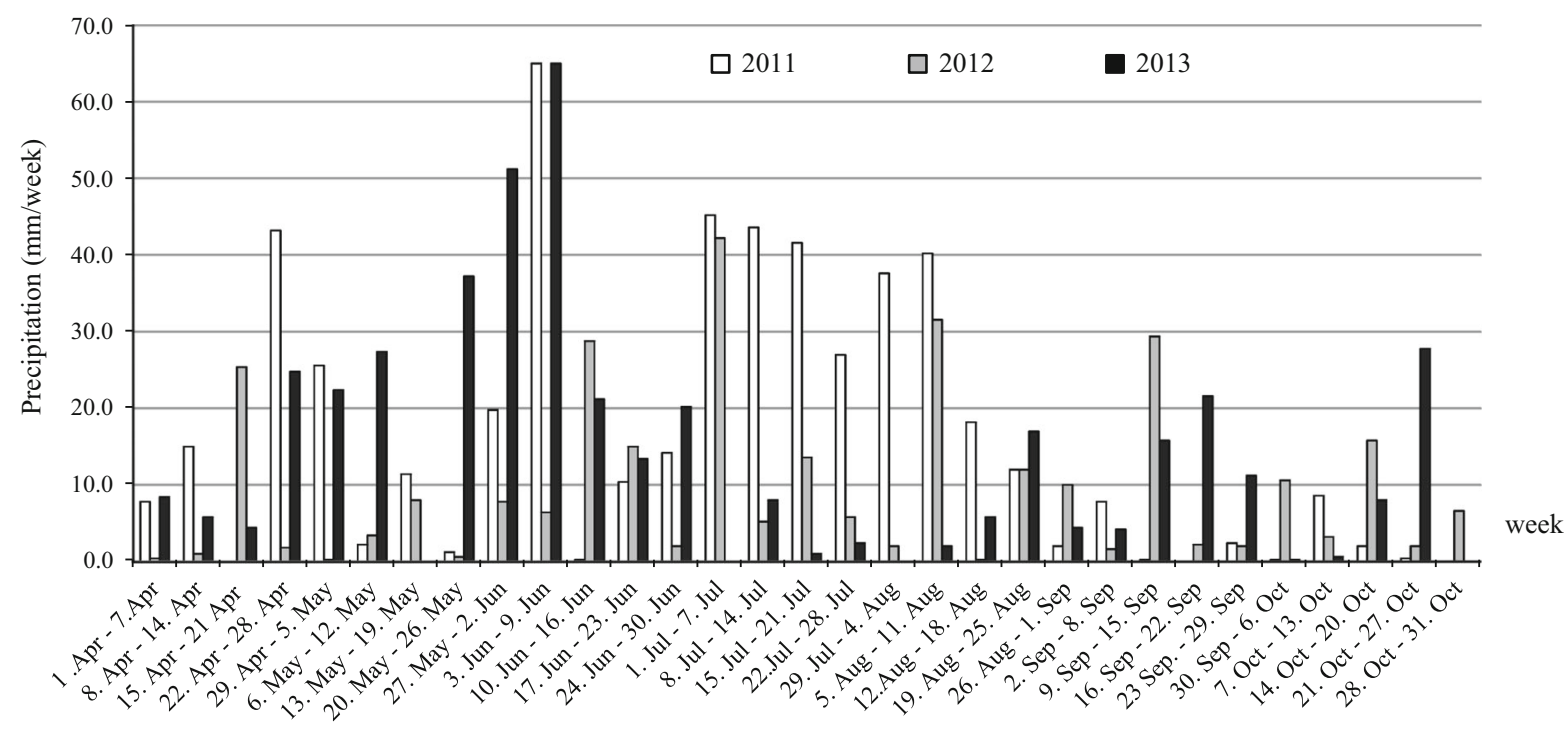

Fig. 1 Mean weekly precipitation during the experiment across years 2011-2013

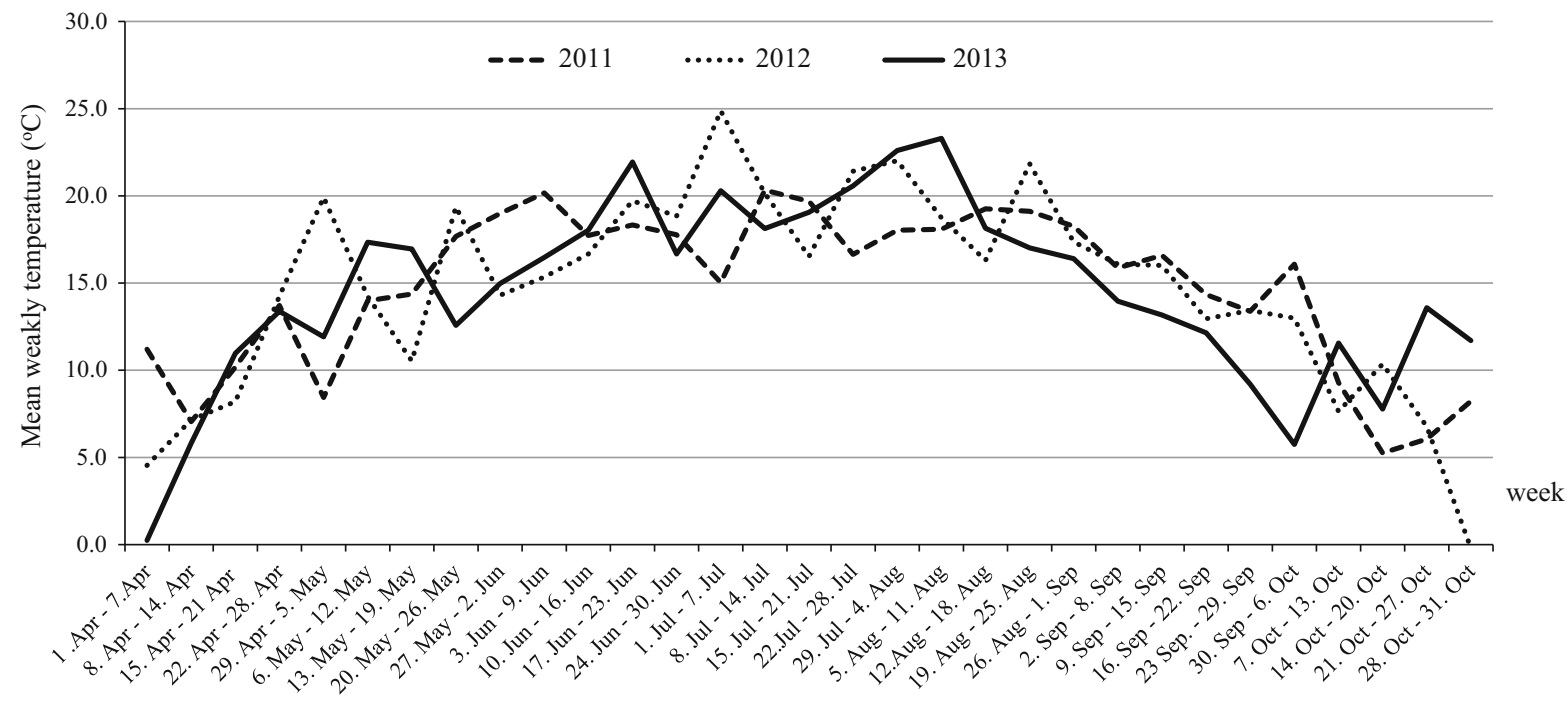

Fig. 2 Mean weekly temperature during the experiment across years 2011-2013

were unusually dry - the total rainfall recorded for this period was only $21.6 \mathrm{~mm}$. The 2011 season was also moderately warm; the mean temperature for each week, from May 20 until September 15 ranged from 15.0 to $20.3{ }^{\circ} \mathrm{C}$.

The 2012 season was quite poor in precipitationfrom April 1 till October 31 a total of $296.8 \mathrm{~mm}$ of rain was recorded. The highest rainfall was recorded in the period from July 1 to $7(42.2 \mathrm{~mm})$ and from August 5 to $11(31.6 \mathrm{~mm})$. The least rainfall $(14.0 \mathrm{~mm})$ was recorded between April 22 and May 26. The year 2012 was marked by a considerably higher mean weekly temperature in July, (reaching up to $25{ }^{\circ} \mathrm{C}$ for July 1-7) compared with the previous season. The maximum temperature during this period exceeded $30^{\circ} \mathrm{C}$.

The 2013 season was moderately abundant in rainfall (from April 1 to October 31 a total rainfall of $431.4 \mathrm{~mm}$ was recorded). The most rainfall came in the last days of May and the first ten days of June-a total of $153.4 \mathrm{~mm}$. The month of July and the first half 
of August were the hottest and dry. In the period from July 1 to August 18, only $19.2 \mathrm{~mm}$ of rainfall was recorded, while the mean temperature over that period was $20.3{ }^{\circ} \mathrm{C}$.

Phenotypic analysis of hybrid families

The study showed significant variation in the severity of leaf diseases within the tested hybrid families. Minor symptoms (Table 2) were observed only in the case of the leaf spot. The mean severity of the disease in different seasons ranged from 0.006 to 0.013 (on a $0-5$ point scale) and therefore was very low. In the 2011 season, slightly higher severity of the disease, compared with the average infection of the seedlings in the test population of hybrid families, was observed on the seedlings of 'Aromas' $\times$ 'Monterey', but the differences were not statistically significant.

In 2012, single spots, indicating slight infection of plants by $M$. fragariae, were found on seedlings of 21 hybrid families. Significantly more affected $(P<0.01)$ by this pathogen, compared with the average for all the hybrid families, were seedlings from the families 'Aromas' $x$ 'Charlotte', 'Aromas' $\times$ 'San Andreas', 'Diamante' $\times$ 'Figaro', 'Portola' $\times$ 'Albion', $\quad$ 'Charlotte' $\times$ 'Palomar', 'Charlotte' $\times$ 'Elianny', 'Monterey' $\times$ 'Albion', 'Monterey' $\times$ 'Elianny', 'Albion' $\times$ 'Palomar', 'Albion' $\times$ 'Camarosa' and 'Figaro' $\times$ 'Elianny'.

By comparison, in 2013, significantly higher severity of the leaf spot, compared with the average infection of the seedlings in the test population, was found in the seedlings of the families 'Aromas' $\times$ 'Monterey', 'Portola' $\times$ 'Albion' and 'Charlotte' $\times$ 'Elianny'. In summary, on average significantly more severe infection of the leaves with M. fragariae for 2011-2013, was found for seedlings of the families 'Aromas' $\times$ 'Portola', 'Aromas' $\times$ 'Monterey', 'Portola' $\times$ 'Albion', 'Charlotte' $\times$ 'Palomar' and 'Charlotte' $\times$ 'Elianny'. Moreover, in the case of hybrids belonging to the listed families, highly significant genotypes $\times$ years $(\mathrm{G} \times \mathrm{Y})$ interaction was estimated (Table 2).

The severity of the leaf scorch in 2011-2013 was much higher than of the leaf spot and the powdery mildew (Table 2). The average severity of the disease on strawberry plants of all the hybrid families in the years 2011, 2012 and 2013 was 1.74, 1.46 and 1.54, respectively. The most symptoms of this disease, among all the tested seedlings, were found on the plants belonging to the families 'Monterey' $\times$ 'Elianny' and 'Aromas' $\times$ Monterey'. The average severity of the leaf scorch obtained for these families was 2.61-2.76.

The mildest infection of leaves by $D$. earliana $(0.71$ to 0.89 points lower compared with the average infection of all the hybrids in the test population; $P<0.01$ ) was observed on seedlings of the families 'Charlotte' $\times$ 'Figaro', 'San Andreas' $\times$ 'Camarosa', 'Salsa' $\times$ 'Palomar', 'Palomar' $\times$ 'Camarosa' and 'Salsa' $\times$ 'Elianny'. In 2012, the most symptoms of the disease $(P<0.01)$ were found on hybrid plants belonging to the families 'Monterey' $\times$ 'Elianny', 'Albion' $\times$ 'Camarosa', 'Diamante' $\times$ 'Portola', 'Monterey' $\times$ 'Figaro', 'Aromas' $\times$ 'Portola' and 'Salsa' $\times$ 'Granda' (0.61-0.87 points higher compared with the average for the entire test population of hybrids).

Significantly lower $(P<0.01)$ than the overall average (estimated for the entire population of hybrids) was the severity of leaf infection by $D$. earliana of seedlings of the families 'Aromas' $\times$ 'Granda', 'Aromas' $\times$ 'Elianny', 'Diamante' $\times$ 'Salsa', 'San Andreas' $\times$ 'Palomar' and 'Granda' $\times$ 'Elianny' (score 0.60-1.06 points lower than the average for all the hybrid families). In 2013, as in 2012, the most symptoms of leaf infection by $D$. earliana were found on seedlings of 'Monterey' $\times$ 'Elianny' and 'Albion' $\times$ 'Camarosa', followed by 'Diamante' $\times$ 'Portola', 'Monterey' $\times$ 'Figaro', 'Aromas' $\times$ 'Portola' and 'Salsa' $\times$ 'Granda' (0.6-0.84 points higher than the overall average; $P<0.01)$.

Significantly lowest severity of leaf scorch $(P<0.01)$ was observed on seedlings of the family 'San Andreas' $\times$ 'Palomar', followed by 'Diamante' $\times$ 'Salsa', 'Aromas' $\times$ 'Elianny', 'Aromas' $\times$ 'Granda', 'San Andreas' $\times$ 'Figaro', 'Aromas' $\times$ 'Palomar', 'Camarosa' $\times$ 'Elianny' and 'Granda' $\times$ 'Elianny' (score 0.60-1.13 points lower than the average estimated for the entire population of hybrids).

The average severity of leaf infection by $D$. earliana in all the seedlings belonging to the 78 hybrid families was 1.58 for the three years of observations. Significantly higher values (by 0.43-0.91 points; $P<0.01$ ), compared with this average, were obtained for nine hybrid families: 


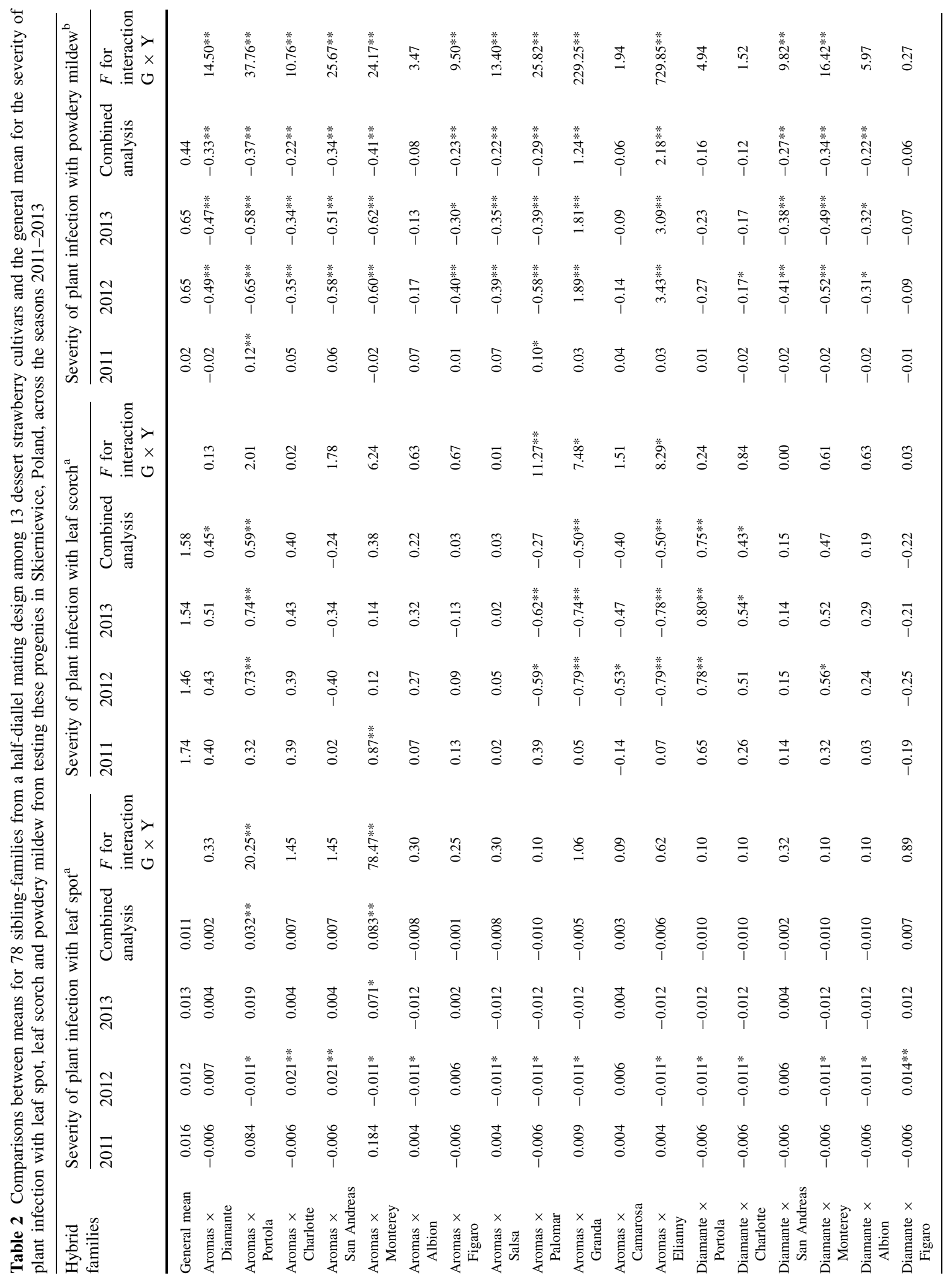




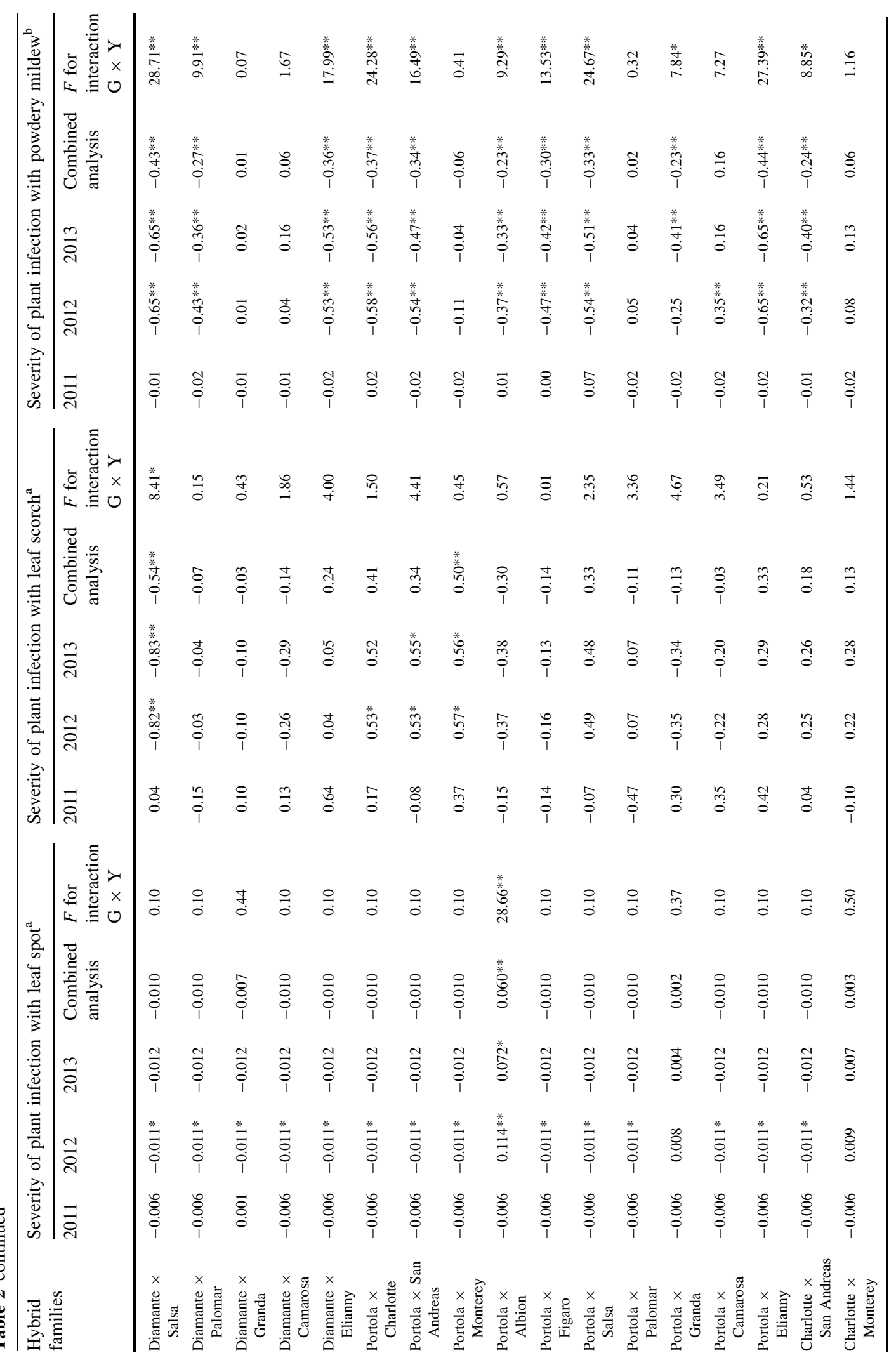




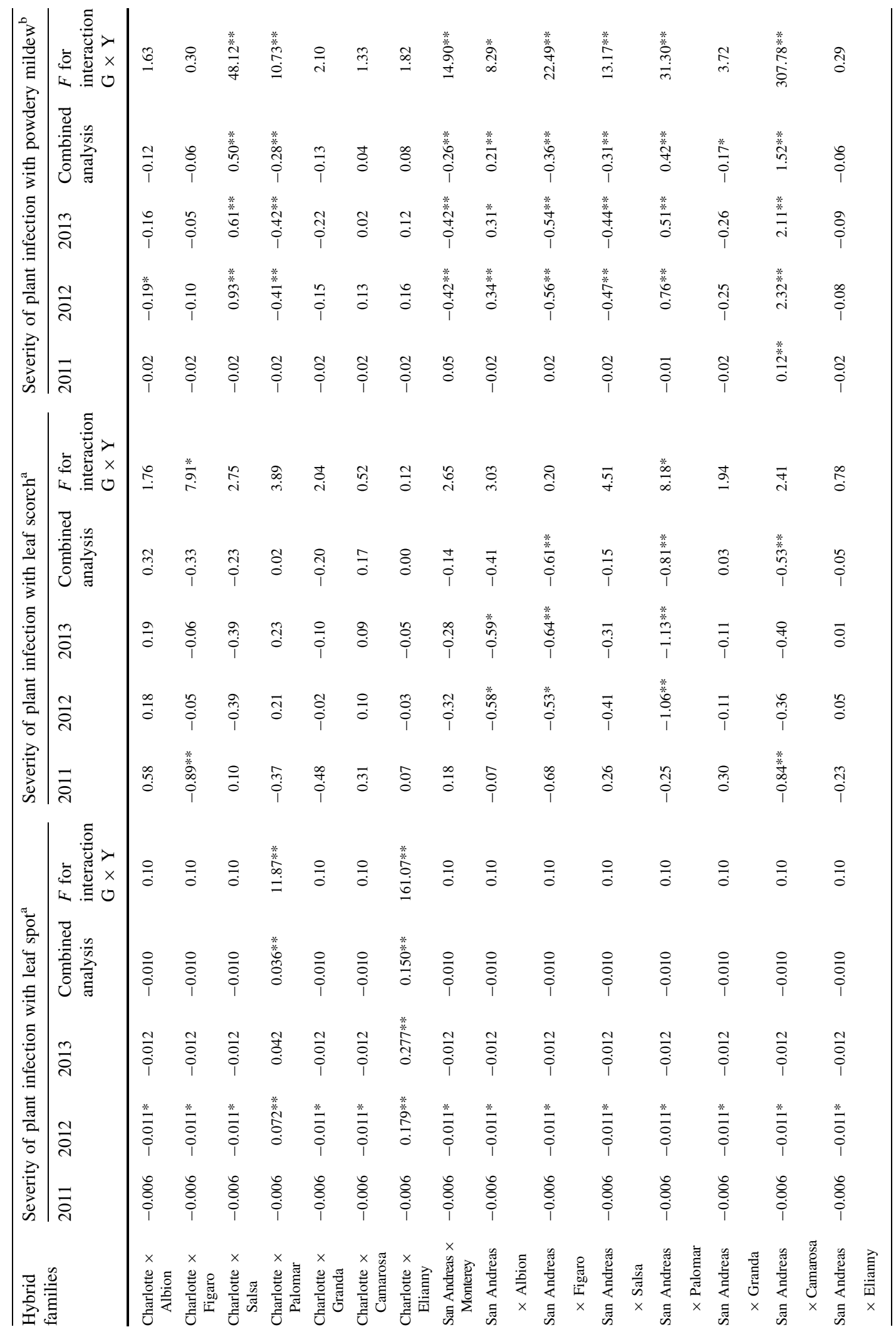




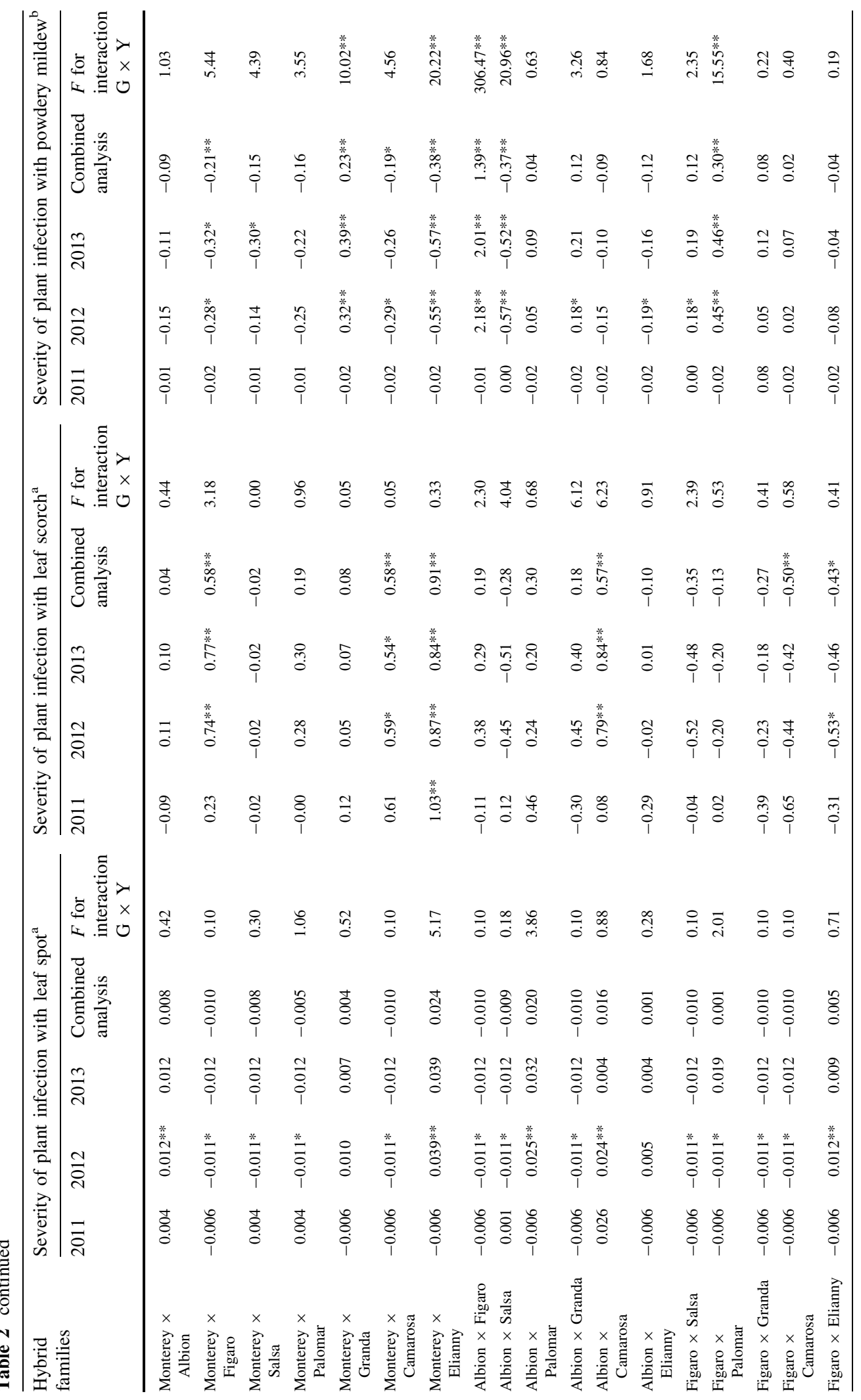




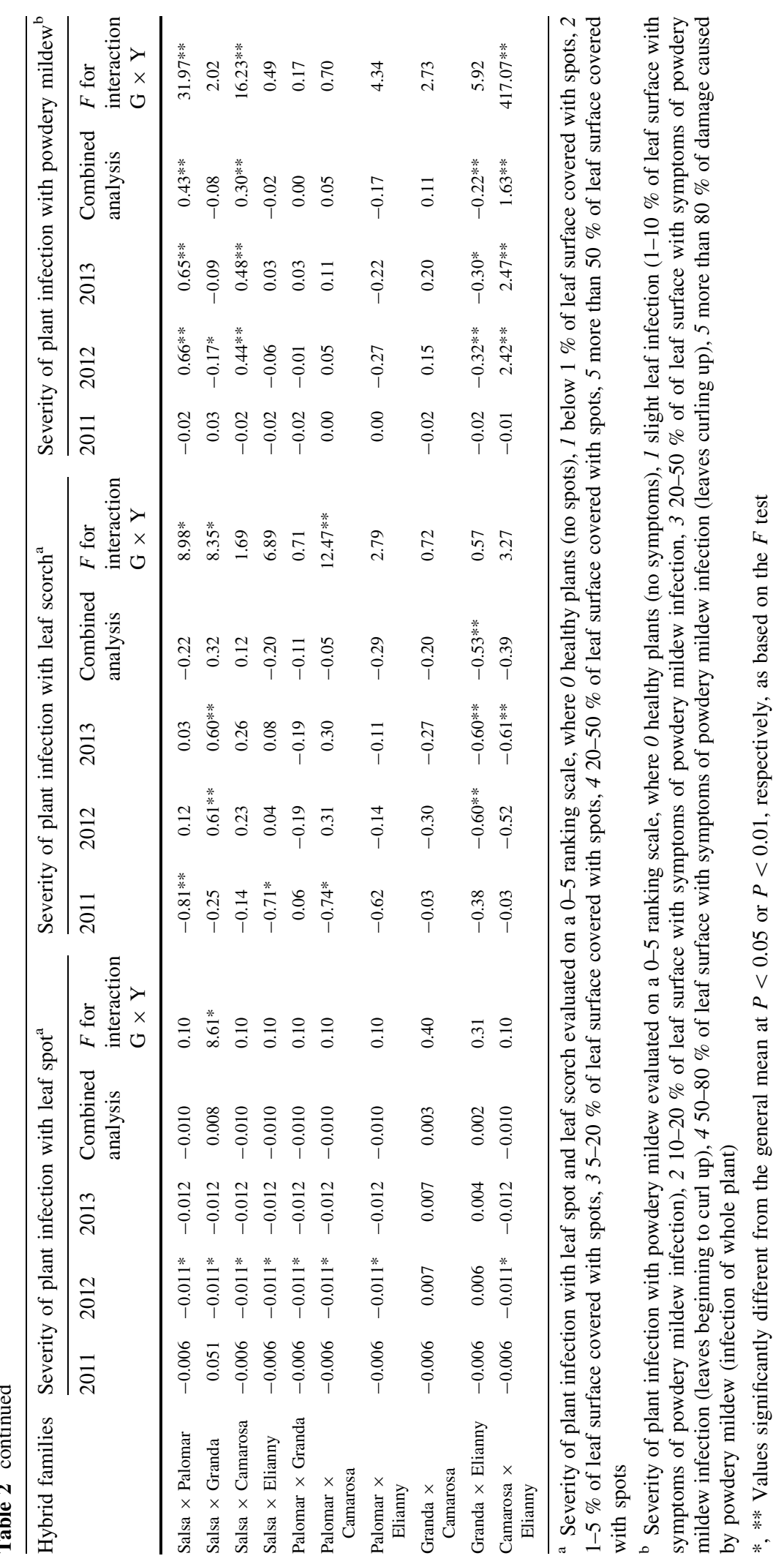


'Aromas' $\times$ 'Diamante', $\quad$ 'Aromas' $\times$ 'Portola', 'Diamante' $\times$ 'Portola', 'Diamante' $\times$ 'Charlotte', 'Portola' $\times$ 'Monterey', 'Monterey' $\times$ 'Figaro', 'Monterey' $x$ 'Camarosa', 'Monterey' $x$ 'Elianny' and 'Albion' $\times$ 'Camarosa'. Significantly lower values for this trait (by $0.43-0.81$ points; $P<0.01$ ) were estimated for seedlings of the following families: 'Aromas' $\times$ 'Granda', 'Aromas' $\times$ 'Elianny', 'Diamante' $\times$ 'Salsa', 'San Andreas' $\times$ 'Figaro', 'San Andreas' $\times$ 'Palomar', 'San Andreas' $\times$ 'Camarosa', 'Figaro' $x$ 'Camarosa', 'Figaro' $\times$ 'Elianny' and 'Granda' $x$ 'Elianny'.

In plants infected by $D$. earliana, the $\mathrm{G} \times \mathrm{Y}$ interaction for most hybrid families was close to zero. However, for hybrid families such as 'Aromas' $\times$ 'Palomar', 'Aromas' $\times$ 'Granda', Aromas' $\times$ 'Elianny', 'Diamante' $\times$ 'Salsa', 'Charlotte' $\times$ 'Figaro', 'San Andreas' $\times$ 'Palomar', 'Salsa' $\times$ 'Palomar', 'Salsa' $\times$ 'Granda' and 'Palomar' $\times$ 'Camarosa', the $\mathrm{G} \times \mathrm{Y}$ interaction was significant $(P<0.05)$.

In 2011-2013, the severity of leaf infection of seedlings by $S$. macularis, estimated for the entire population of the hybrids tested, was low $(0.02,0.65$ and 0.65 in 2011, 2012 and 2013, respectively, with an average of 0.44 on a $0-5$ scale, Table 2). This means that the lowest severity of leaf infection by $S$. macularis of all the tested hybrids was recorded in 2011. The highest severity of powdery mildew, significantly different from the average for all the hybrids tested (score of $0.12 ; P<0.01$ ), was observed on the leaves of seedlings belonging to two hybrid families: 'Aromas' $\times$ 'Portola' and 'San Andreas' $x$ 'Camarosa'. No symptoms of the disease were found on plants belonging to 43 families.

In 2012, fairly extensive symptoms of powdery mildew (2.18-3.43 points higher than the average for all the hybrid families; $P<0.01$ ) were observed on the leaves of seedlings belonging to the families: 'Aromas' $x$ 'Elianny', 'Camarosa' $\times$ 'Elianny', 'San Andreas' $x$ 'Camarosa' and 'Albion' $x$ 'Figaro'. Also in the case of nine other families, the severity of infection of the seedlings was estimated to be significantly higher (by $0.18-1.89$ points; $P<0.01)$ compared with the average for the entire population. Plants of three families ('Aromas' $\times$ 'Portola', 'Diamante' $\times$ 'Salsa' and 'Portola' $\times$ 'Elianny') exhibited no symptoms of infection.
In 2013, alike in 2012, the most affected by $S$. macularis were hybrids of the families: 'Aromas' $x$ 'Elianny', 'Camarosa' $\times$ 'Elianny', 'San Andreas' $x$ 'Camarosa' and 'Albion' $\times$ 'Figaro' (scores by 3.09, 2.47, 2.11 and 2.01 points higher, respectively, compared with the average for the population; $P<0.01$ ). Hybrids of two families, 'Diamante' $\times$ 'Salsa' and 'Portola' $\times$ 'Elianny', did not show any signs of infection.

For the years 2011-2013, on average, the most extensive symptoms of leaf infection with powdery mildew were observed in seedlings of the hybrid families: 'Aromas' $\times$ 'Elianny', 'Camarosa' $\times$ 'Elianny', 'San Andreas' $\times$ 'Camarosa' and 'Albion' $\times$ 'Figaro' (higher by 2.18, 1.63, 1.52 and 1.39 points, respectively, compared with the average for the entire population of hybrids; $P<0.01)$. Significantly higher severity of leaf infection (by $0.21-1.24$ points), with respect to the average for all the hybrid families, was also shown by eight other hybrid families. In the hybrids 'Portola' $\times$ 'Elianny', no symptoms of leaf infection were found in any of the three years of the study (Table 2). In 39 of the 78 hybrid families tested, significant $\mathrm{G} \times \mathrm{Y}$ interactions were found.

\section{Analysis of variance}

The analysis of variance of the experimental data showed significant variation $(P<0.01)$ in the GCA and SCA effects of the tested parental genotypes (G) of strawberry, as well as in their interaction with the years of the study (Y) for all of the traits analyzed (Table 3). The values of the general predicted ratio (GPR) for the GCA and SCA effects, defining the relative importance of additive and non-additive effects in the inheritance of the susceptibility of plants to fungal diseases of leaves in the gene pool studied, were: 0.16 for leaf spot, 0.41 for leaf scorch, and 0.19 for the powdery mildew of strawberry.

\section{GCA analysis}

Estimates of GCA effects of the parental forms of strawberry in terms of plant infection by $M$. fragariae, D. earliana and S. macularis are provided in Table 4. The negative and positive values of GCA effects indicate high plant resistance and high susceptibility to these diseases respectively. With the exception of the 
Table 3 Combined (multi-year) analysis of variance for the severity of plant infection with leaf spot, leaf scorch and powdery mildew of 78 sibling families from a half-diallel mating design among 13 dessert strawberry cultivars from testing these progenies in Skierniewice, Poland, across the 2011-2013 seasons

\begin{tabular}{lccrc}
\hline Source of variation & Degrees of freedom & \multicolumn{2}{l}{ Average mean squares for severity of plant infection with } \\
\cline { 3 - 4 } & & Leaf spot ${ }^{\mathrm{a}}$ & Leaf scorch $^{\mathrm{a}}$ & Powdery mildew $^{\mathrm{b}}$ \\
\hline Hybrid families (G) & 77 & $1611.5^{* *}$ & $0.37^{* *}$ & $6784.9^{* * *}$ \\
Years (Y) & 2 & 950.7 & 1.62 & $102,936.1^{* *}$ \\
G $\times$ Y & 154 & $559.3^{* *}$ & $0.08^{* *}$ & $1699.5^{* *}$ \\
GCA & 12 & $155.8^{* *}$ & $0.09^{* *}$ & $774.8^{* *}$ \\
GCA $\times$ Y & 24 & $65.37^{* *}$ & $0.01^{* *}$ & $191.9^{* *}$ \\
SCA & 65 & $1592.6^{* *}$ & $0.26^{* *}$ & $6464.0^{* *}$ \\
SCA $\times$ Y & 130 & $529.9^{* *}$ & $0.08^{* *}$ & $1623.6^{* *}$ \\
GPR & & 0.16 & 0.41 & 0.19
\end{tabular}

$\overline{G C A}$ general combining ability, $S C A$ specific combining ability, $G P R$ general predicted ratio: $\mathrm{GCA} / \mathrm{SCA}=(2 \mathrm{MS} \mathrm{GCA}) /$ $\left(2 \mathrm{MS}_{\mathrm{GCA}}+\mathrm{MS}_{\mathrm{SCA}}\right)$

a Severity of plant infection with leaf spot and leaf scorch evaluated on a $0-5$ ranking scale, where 0 healthy plants (no spots), 1 below $1 \%$ of leaf surface covered with spots, $21-5 \%$ of leaf surface covered with spots, $35-20 \%$ of leaf surface covered with spots, $420-50 \%$ of leaf surface covered with spots, 5 more than $50 \%$ of leaf surface covered with spots

b Severity of plant infection with powdery mildew evaluated on a $0-5$ ranking scale, where 0 healthy plants (no symptoms), 1 slight leaf infection (1-10\% of leaf surface with symptoms of powdery mildew infection), $210-20 \%$ of leaf surface with symptoms of powdery mildew infection, $320-50 \%$ of of leaf surface with symptoms of powdery mildew infection (leaves beginning to curl up), 4 $50-80 \%$ of leaf surface with symptoms of powdery mildew infection (leaves curling up), 5 more than $80 \%$ of damage caused by powdery mildew (infection of whole plant)

*, ** Significant differences of GCA or SCA effects at $P<0.05$ or $P<0.01$, respectively, as based on $F$ test

2011 field season, significant GCA effects were observed with the three leaf diseases examined in this study. Only for the severity of the leaf spot, all the GCA effects estimated in 2011, were not statistically significant, and their values were close to zero. The statistically proven GCA effects for the tested parental genotypes in relation to that trait were obtained generally only in one year of the study (less often in two years) and also for the overall average for the three years of the study. Significantly positive values $(P<0.01)$ of GCA effects were estimated for the varieties 'Charlotte' and 'Elianny' in 2012 and 2013, as well as for 'Albion' in 2012. These cultivars also exhibited significantly positive GCA effects for the average severity of plant infection during the three years of research. At the same time, highly significant GCA $\times$ years interaction was estimated for these genotypes. Significantly negative values of the GCA effects $(P<0.01)$ were estimated only in 2012 for the following varieties: 'Diamante', 'San Andreas', 'Figaro', 'Salsa', Granda' and 'Camarosa'.

Statistically GCA effects for the severity of the leaf scorch in each of the three years of the study as well as for the three-year average were estimated for two parental genotypes. For 'Monterey', these effects had a positive sign, whereas for the variety 'Figaro' they were negative $(P<0.01)$. Significantly positive values $(P<0.01)$ of the GCA effects for this trait were also obtained for the varieties 'Portola' and 'Charlotte' (in 2012 and 2013, and for the three-year average), 'Diamante' (in 2011 and for the three-year average), and 'Aromas' (in 2011). Significantly negative GCA effects for the severity of leaf scorch were estimated for the cultivars 'San Andreas' $(P<0.01)$ and 'Granda' $(P<0.05)$ in two seasons, and for 'Palomar' $(P<0.01)$ in one year. All these genotypes and additionally 'Salsa', showed statistically proven negative GCA effects for the average values of the severity of this disease across the three years of research.

Statistically significant $(P<0.01)$ effects of GCA for the severity of the powdery mildew, estimated in at least two out of the three years of the study, as well as for the three-year average, were found for nine parental genotypes. For the cultivars 'Aromas', 'Figaro', 'Granda', 'Camarosa' and 'Elianny', the values 


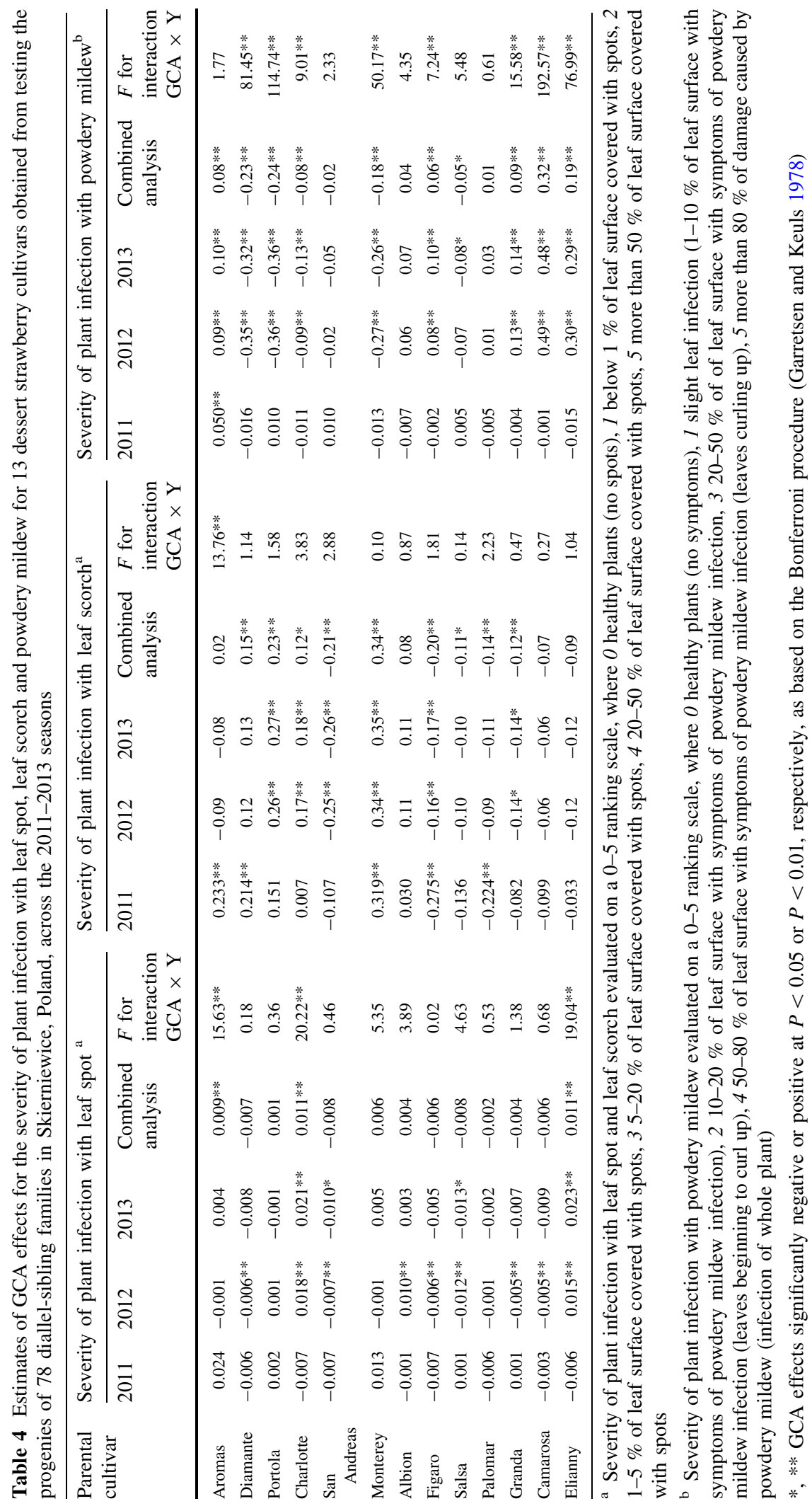


of GCA effects were positive. Significantly negative values of GCA effects for this trait were estimated for the cultivars: 'Diamante', 'Portola', 'Charlotte' and 'Monterey' (for 2012 and 2013, and the 2011-2013 average; $P<0.01$ ), as well as 'Salsa' (for 2013 and the 2011-2013 average; $P<0.05$ ). For these cultivars, with exception for 'Aromas' and 'Salsa', the estimated GCA $\times$ years interaction was highly significant.

\section{SCA analysis}

The results of the estimated SCA effects of the crossed parental forms of strawberry for the severity of plant infection by $M$. fragariae, D. earliana and S. macularis are provided in Table 5. The negative and positive SCA values indicate high plant resistance and high susceptibility to these diseases respectively. For some hybrid families, the agreement between the values of SCA effects in the individual years of observations was low, which was confirmed statistically by estimating a significant $\mathrm{SCA} \times$ years interaction.

With regard to the leaf spot, the most (i.e. as many as 39) significant $(P<0.01)$ SCA effects were observed in 2012 (Table 5). These effects produced positive values for 15 families. The highest were for the families: 'Charlotte' $\times$ 'Elianny' and 'Portola' $\times$ 'Albion'. Significantly negative SCA effects were shown by 24 hybrid families: 'Aromas' $\times$ 'Portola', 'Aromas' $\times$ 'Albion', 'Aromas' $\times$ 'Elianny', 'Diamante' $\times$ 'Charlotte', 'Diamante' $\times$ 'Albion', 'Diamante' $\times$ 'Elianny', 'Portola' $\times$ 'Charlotte', 'Portola' $\times$ 'Monterey', 'Portola' $\times$ 'Palomar', 'Portola' $\times$ 'Elianny', 'Charlotte' $\times$ 'San Andreas', 'Charlotte' $\times$ 'Albion', 'Charlotte' $\times$ 'Figaro', 'Charlotte' $\times$ 'Salsa', 'Charlotte' $\times$ 'Granda', 'Charlotte' $\times$ 'Camarosa', 'San Andreas' $\times$ 'Albion', 'San Andreas' $\times$ 'Elianny', 'Albion' $\times$ 'Figaro', 'Albion' $\times$ 'Granda', 'Albion' $\times$ 'Elianny', 'Salsa' $\times$ 'Elianny', 'Palomar' $\times$ 'Elianny' and 'Camarosa' $x$ 'Elianny'.

In 2013, significant leaf spot SCA effects were found for only three families: 'Aromas' $\times$ 'Monterey', 'Portola' $\times$ 'Albion' and 'Charlotte' $\times$ 'Elianny'. All of these SCA effects were positive. In 2011, the SCA effects for all of the hybrid families were not significant and close to zero. SCA effects significantly different from zero, as estimated on the basis of the average severity of leaf spot (mean score for 2011-2013), were found for nine hybrid families (Table 5). These effects produced positive values for the following families: 'Aromas' $x$ 'Monterey', 'Portola' $\times$ 'Albion', 'Charlotte' $\times$ 'Elianny', 'Diamante' $\times$ 'Figaro', 'Charlotte' $\times$ 'Palomar' and 'Salsa' $\times$ 'Granda'. Significantly negative effects of SCA were obtained for three hybrid families: "Aromas' $\times$ 'Elianny', 'Portola' $\times$ 'Charlotte' and 'Charlotte' $x$ 'Albion'. Moreover, the SCA $x$ years interaction for these hybrid families was not significant and close to zero.

For the severity of plant infection by D. earliana, statistically proven SCA effects for the tested parental genotypes were obtained in two years of the study (2012 and 2013), as well as for the average for the three years of the study (Table 5). In 2011, there were only two SCA effects with values significantly different from zero. Both effects were positive and obtained for the hybrid families 'Monterey' $x$ 'Elianny' and 'Albion' $x$ 'Palomar'. Significantly positive $(P<0.05)$ SCA effects in 2012-2013, and also on average across all the years of the study, were estimated for the following hybrid families: 'Portola' $\times$ 'San Andreas', 'Monterey' $\times$ 'Figaro', 'Monterey' $x$ 'Elianny', 'Albion' $x$ 'Camarosa' and 'Salsa' $\times$ 'Granda', as well as 'Aromas' $\times$ 'Portola' (significantly positive SCA effects for 2012 and 2013, but not for the three-year average). Significantly negative SCA values, estimated in at least two years and on the basis of the mean scores for the three years of the study, were apparent with the following hybrid families: 'Aromas' $\times$ 'Granda', 'Aromas' $\times$ 'Elianny', 'Diamante' $\times$ 'Salsa', 'Portola' $\times$ 'Albion' and 'San Andreas' $\times$ 'Palomar'. At the same time, the families 'Aromas' $\times$ 'Granda', 'Aromas' $x$ 'Elianny' oraz 'Portola' $\times$ 'Albion' showed no SCA $\times$ years correlation, while the other two hybrid families ('Diamante' $\times$ 'Salsa' and 'San Andreas' $x$ 'Palomar') showed a significant SCA $x$ years interaction.

The severity of the powdery mildew was a trait for which the most statistically proven SCA effects were estimated in 2012-2013 (Table 5). As many as 45 statistically proven $(P<0.05)$ SCA effects were observed in 2012 and for the 2011-2013 average, of which 43 and 44 effects were highly significant $(P<0.01)$. In 2013, SCA effects with values significantly different from zero $(P<0.05)$ were found for 


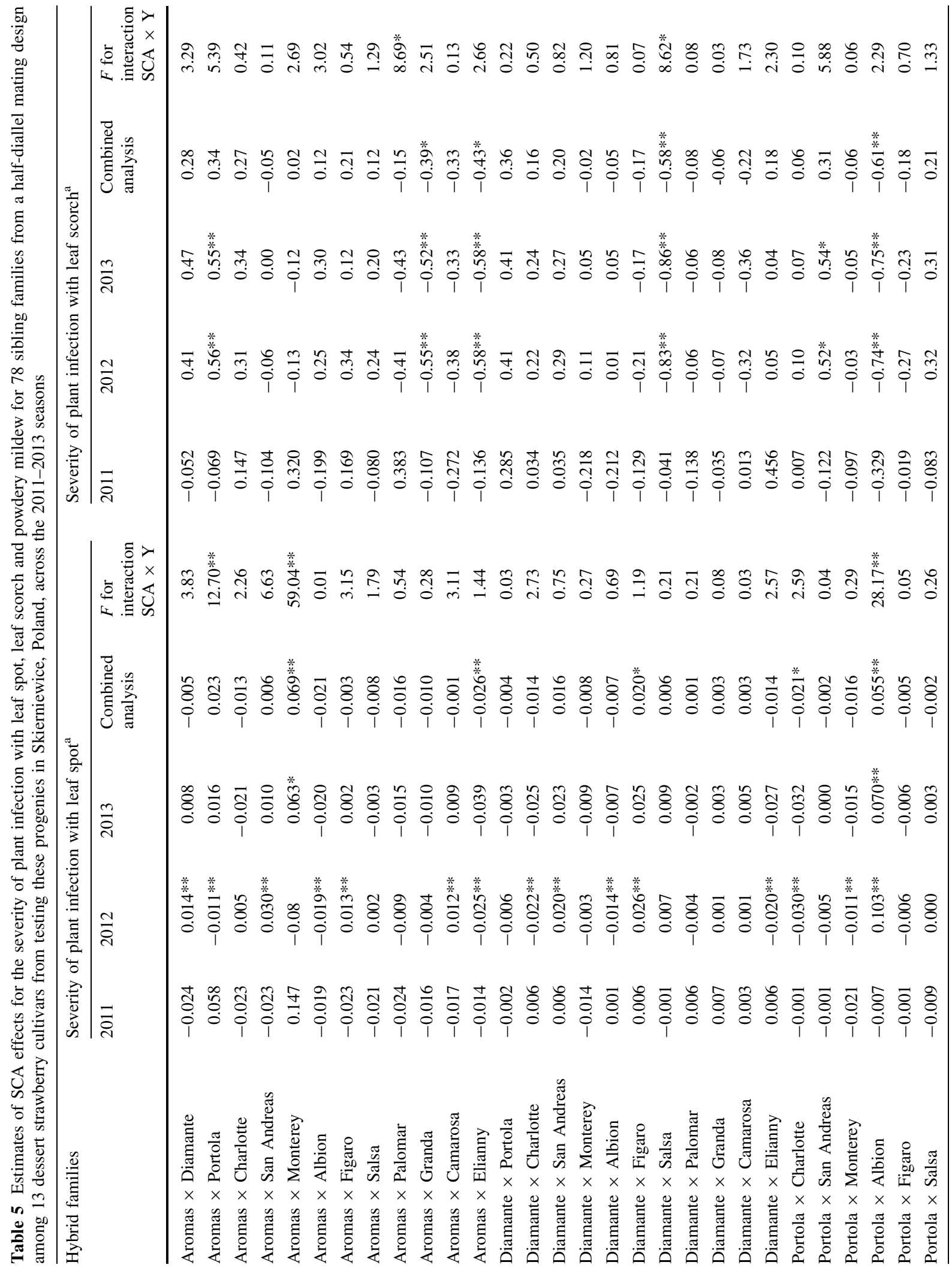




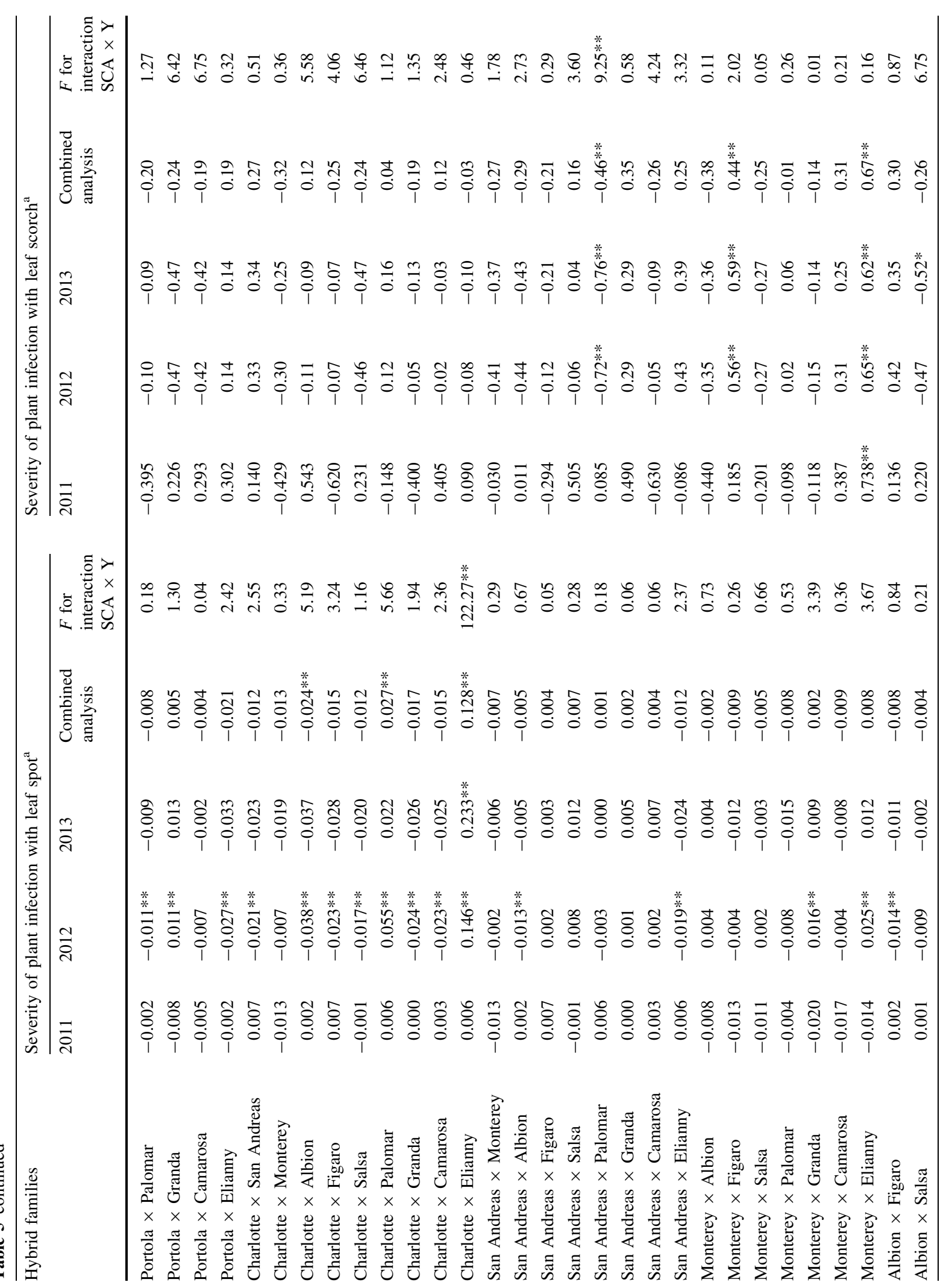




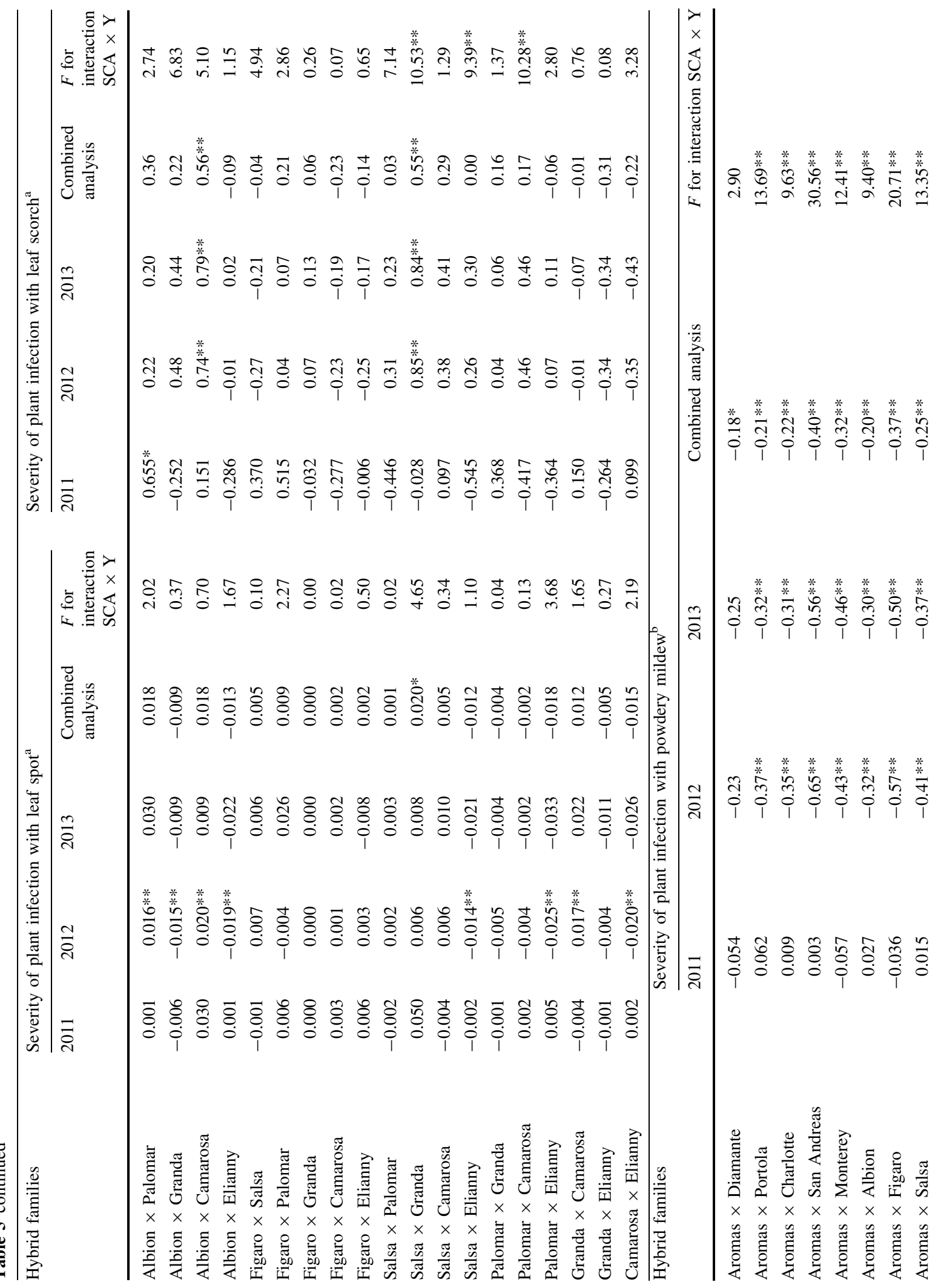




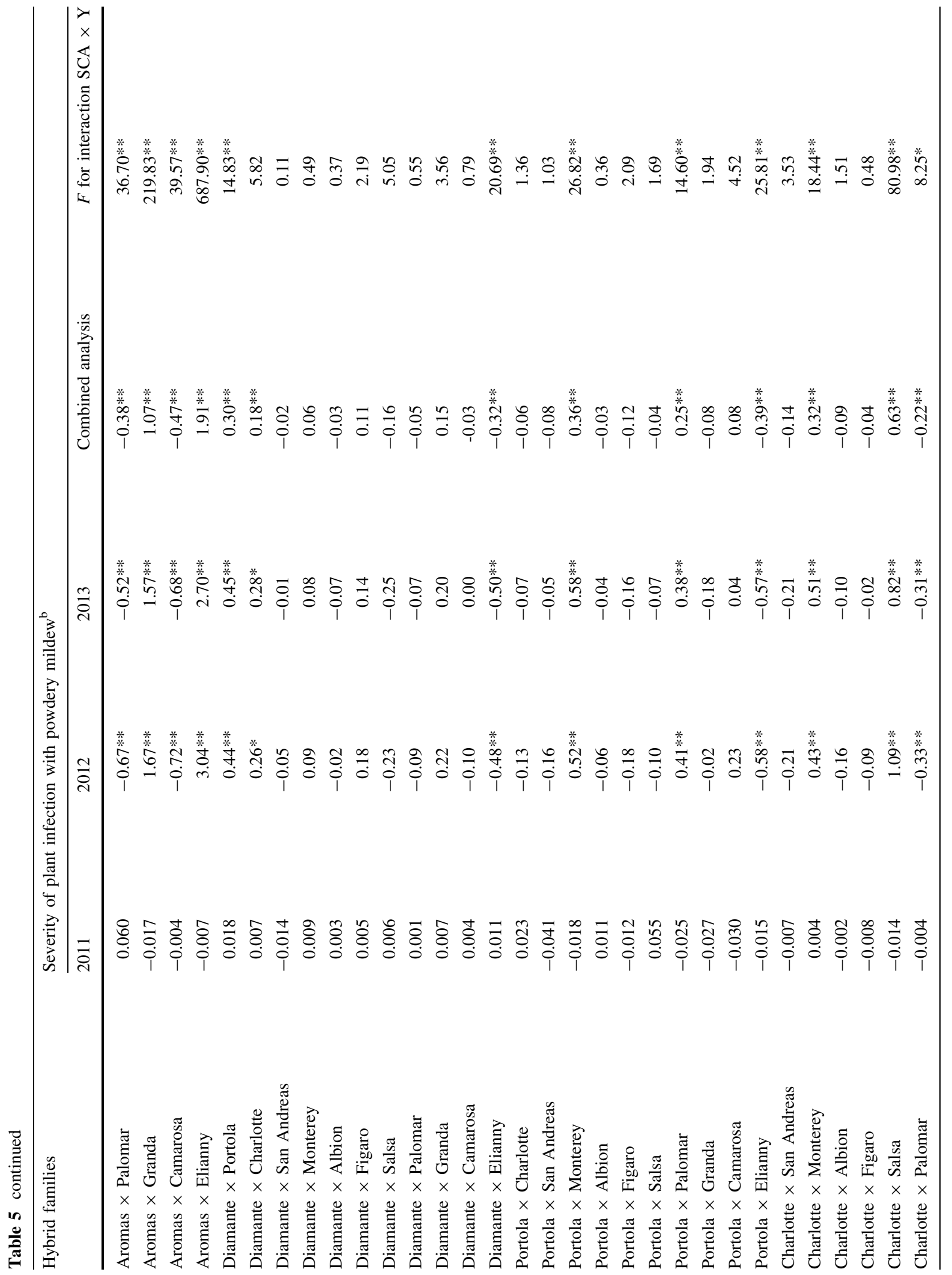




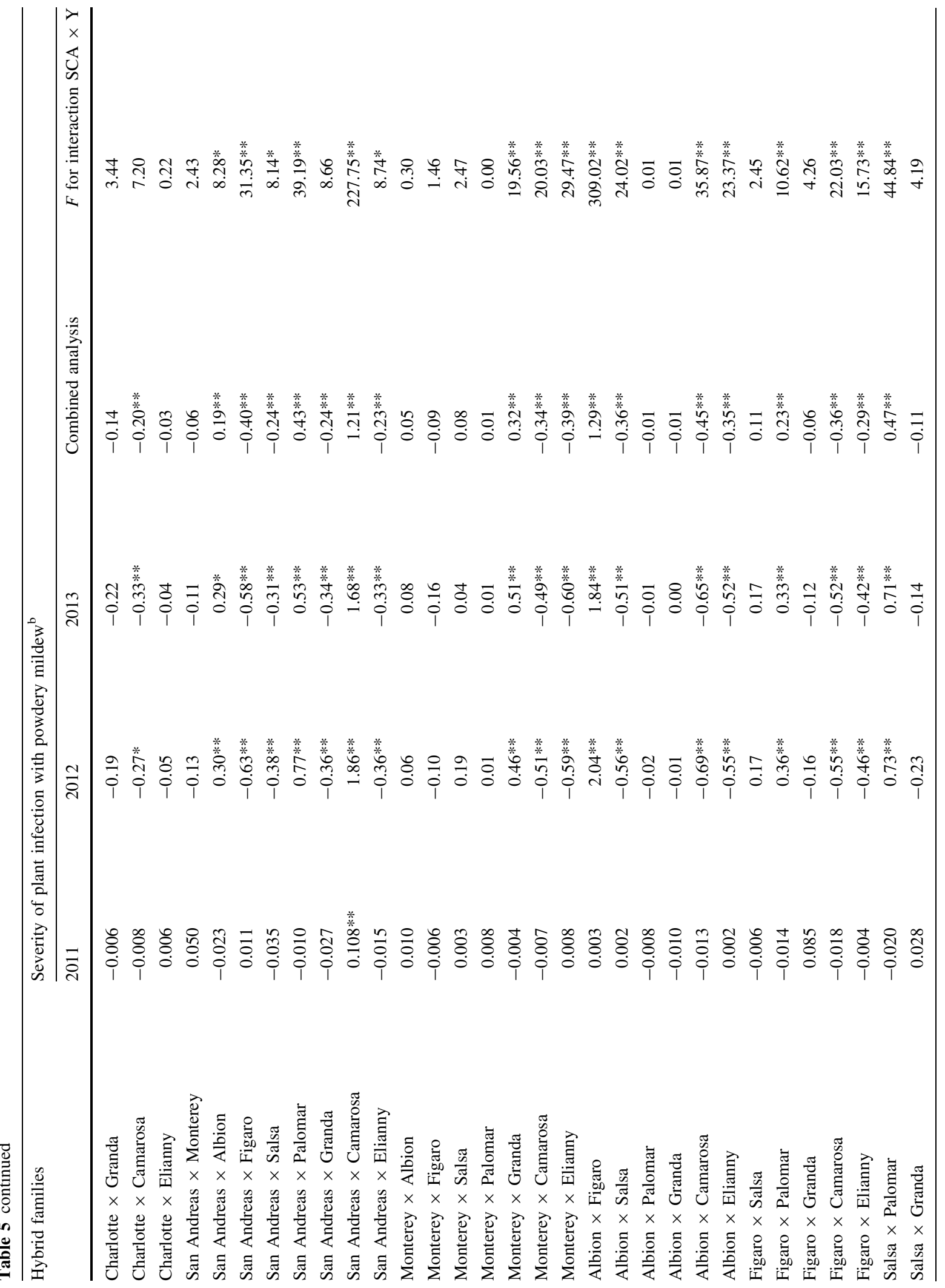




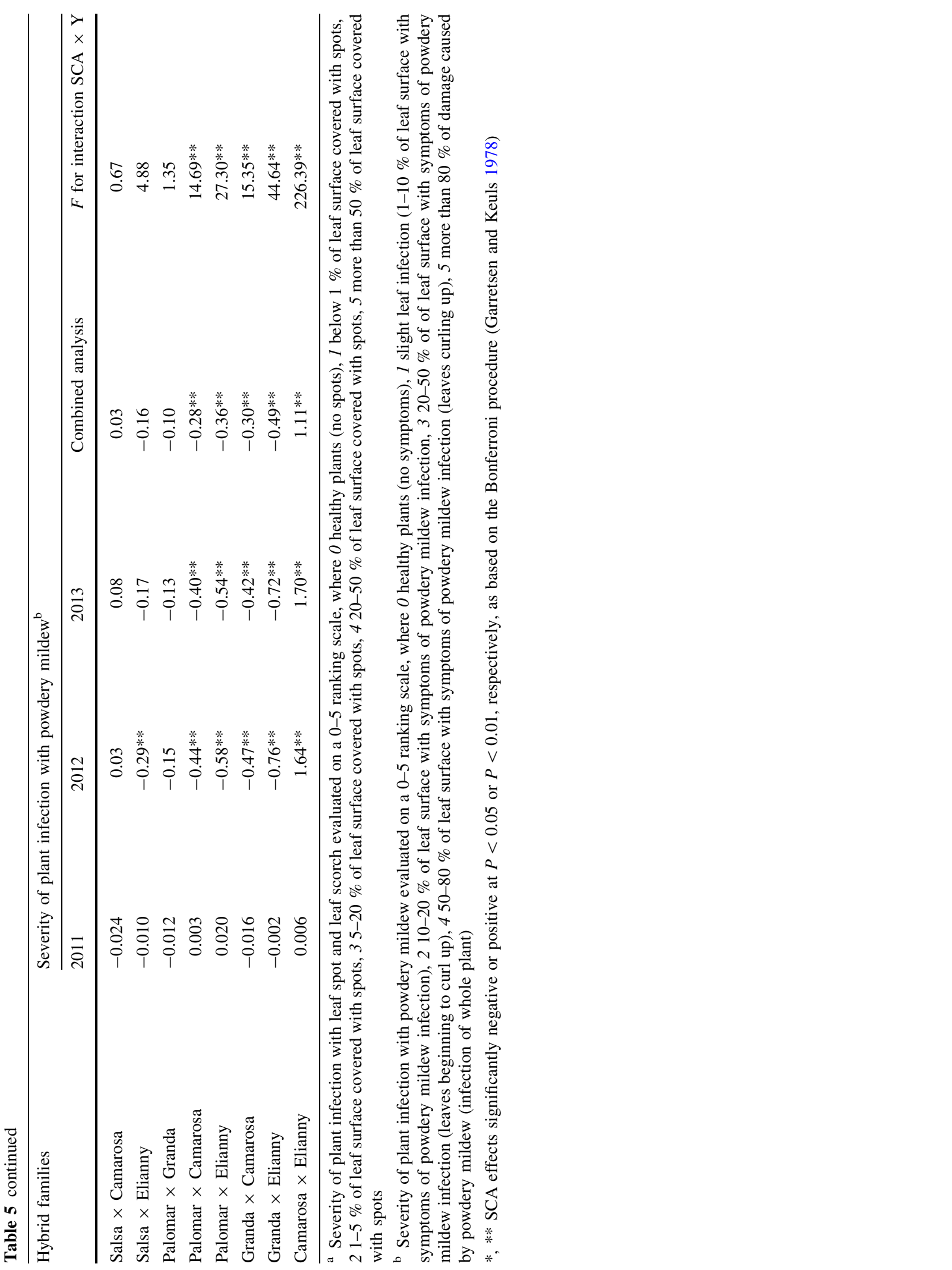


44 hybrid families, but for only one family in 2011 . For 16 hybrid families, the SCA effects (estimated in at least two years and for the 2011-2013 average) took on positive values. SCA effects with negative values were estimated for 27 hybrid families: 'Aromas' $\times$ 'Portola', 'Aromas' $\times$ 'Charlotte', 'Aromas' $\times$ 'San Andreas', 'Aromas' $\times$ 'Monterey', 'Aromas' $\times$ 'Albion', 'Aromas' $\times$ 'Figaro', 'Aromas' $\times$ 'Salsa', 'Aromas' $\times$ 'Palomar', 'Aromas' $\times$ 'Camarosa', 'Diamante' $\times$ 'Elianny', 'Portola' $\times$ 'Elianny', 'Charlotte' $\times$ 'Palomar', 'Charlotte' $\times$ 'Camarosa', 'San Andreas' $\times$ 'Figaro', 'San Andreas' $\times$ 'Salsa', 'San Andreas' $x$ 'Granda', 'San Andreas' $x$ 'Elianny', 'Monterey' $x$ 'Camarosa', 'Monterey' $x$ 'Elianny', 'Albion' $\times$ 'Salsa', 'Albion' $\times$ 'Camarosa', 'Albion' $x$ 'Elianny', 'Figaro' $x$ 'Camarosa', 'Figaro' $\times$ 'Elianny', 'Palomar' $\times$ 'Camarosa', 'Palomar' $\times$ 'Elianny', 'Granda' $\times$ 'Camarosa' and 'Granda' $\times$ 'Elianny'. However, for most of these pairs of parental forms, a significant SCA $\times$ years interaction was also estimated.

\section{Discussion}

Breeding strawberry for the resistance or low susceptibility to serious leaf diseases caused by $M$. fragariae, D. earliana and S. macularis, is very difficult because the traits are polygenic controlled and determined mainly by non-additive effects of genes. The results presented here illustrate that both additive genetic effects (GCA) and non-additive effects (SCA) are important in the genetic determination of these traits. However, low values of the general predicted ratio (GPR), estimated for the severity of plant infection with the leaf spot and the powdery mildew suggest that these traits are determined to a much greater extent by the non-additive genetic effects than by the additive effects. The results obtained are consistent with the hypothesis of strawberry plant resistance inheritance to powdery mildew developed by Hsu et al. (1969), which emphasizes that non-additive variance is more important than additive variance and indicates the significance of epistatic components. Evidence of the importance of non-additive effects in the determination of powdery mildew resistance had also been provided by the research of Daubeny (1961). By contrast, Simpson (1987), while evaluating the progeny of remontant varieties of strawberry had proven that additive effects are dominant in the inheritance of the trait of powdery mildew susceptibility. Likewise, Davik and Honne (2005), MacLachlan (1978), and McNicol and Gooding (1979) had proposed a quantitative model of the inheritance of resistance to powdery mildew, in which the additive variance (GCA) is of a far greater importance, while the non-additive (SCA) effects, although also significant, are less important. In a study by Davik and Honne (2005), specific combining ability variance represented only $10-13 \%$ of the total combining ability.

The significant share of non-additive effects in the genetic determination of resistance/low susceptibility to the three leaf diseases presents a great difficulty in fast breeding of resistant or low-susceptible varieties. An additional difficulty, especially in the breeding of cultivars resistant to powdery mildew, is the occurrence of a strong genotype-environment interaction. A study by Nelson et al. (1995), conducted in the USA with progenies of 17 hybrid families under natural (field) and controlled (greenhouse) conditions indicated, that the weak correspondence between genetic resistance mechanisms with differing severities of infection was a reason for caution due to different genes possibly conferring resistance under different inoculum levels. Use of resistance expressed only under conditions of severe infection may ignore valuable components of partial resistance.

Minor symptoms of strawberry plant infection by $M$. fragariae, observed on the leaves of some hybrids in the form of single small spots with a purple border and grey centre (Howard et al. 1985), or the absence of them in the majority of the individuals being assessed, were likely caused by the weather conditions not being conducive to the development of this disease. At the same time, in the case of some hybrid families, we found a highly significant genotypes $\times$ years interaction, which leads to the conclusion that the weather conditions in the different growing seasons had a highly significant impact on the severity of symptoms in the hybrids of these families. Despite the variations in temperature and precipitation in individual weeks (registered in the period from April 1 to October 31 in 2011, 2012 and 2013), it was observed that during periods of high humidity the air temperature was too low for dynamic development of the fungus, whereas under high air temperature a prolonged drought was 
recorded. It is considered, that the optimum conditions for $M$. fragariae infection and rapid appearance of the characteristic spots on strawberry leaves are high air humidity and temperature in the range $20-25^{\circ} \mathrm{C}$ occurring at the same time (Howard et al. 1985, Carisse et al. 2000). Carisse et al. (2000) had observed germination of up to $92 \%$ of spores of the fungus $M$. fragariae at $25^{\circ} \mathrm{C}$, while at 5,15 and $35^{\circ} \mathrm{C}$ the spore germination percentage was 15,40 and $2 \%$, respectively. According to these authors, the described spore germination can only occur under high levels of moisture on the leaves, persisting for at least $12 \mathrm{~h}$.

In our study, we found that all the hybrids with no visible symptoms of plant infection by $M$. fragariae had been derived from the cultivars 'Diamante', 'San Andreas', 'Figaro', 'Salsa', 'Granda' and 'Camarosa'. Our previous studies (Masny and Żurawicz 2009, 2010), had confirmed the high resistance of the cultivars 'Figaro', 'Salsa' and 'Camarosa' against this pathogen in the climatic conditions of central Poland. The low susceptibility of 'Diamante' and 'San Andreas' plants to $M$. fragariae had also been reported by Finn (1999) and Lewers (2010), as well as Kupczak (2013) and Masny and Żurawicz (2013). The significantly negative values of general combining ability effects estimated for these parental forms for the severity of leaf infection by $M$. fragariae confirm the high value of these cultivars as donors of the trait of high resistance to this pathogen.

The infection of the tested strawberry hybrids by $D$. earliana was significantly more severe than by $M$. fragariae or S. macularis. Numerous irregular, purplish or brownish blotches, $1-5 \mathrm{~mm}$ in diameter, characteristic to this disease (Maas 1998), were observed on the leaves of all the seedlings. The average severity of plant infection, estimated for all the hybrid families, was $1.74,1.46$ and 1.54 in 2011, 2012 and 2013, respectively. At the same time, the genotypes $\times$ years interaction was close to zero for most families, meaning that in all the years of the study these genotypes were affected by $D$. earliana to a similar degree, regardless of the prevailing weather conditions. However, despite the report by Howard et al. (1985), indicating that leaf scorch develops regardless of weather conditions and its severity depends entirely on the susceptibility of the genotype, the most extensive symptoms of the disease were observed in 2011. Presumably, this was a result of more abundant, and more regular rainfall (compared with the subsequent years of the study), which was conducive to the spread of fungal spores and resulting infection (Bielenin et al. 1998). Indeed, it has been proven that the development of the leaf scorch is inhibited not only under drought conditions but also at high (above $35{ }^{\circ} \mathrm{C}$ ) and low (below $-4{ }^{\circ} \mathrm{C}$ ) temperatures (Maas 1998). Despite such a wide temperature range for $D$. earliana development, the most optimal temperature for conidial germination, growth and sporulation is a temperature range of $20-25^{\circ} \mathrm{C}$ (Dhanvantari 1967). In contrast to $M$. fragariae, which affects young developing leaves (Carisse et al. 2000), D. earliana infects mainly older leaves (Zheng and Sutton 1994), often causing them to wither away all at once, sometimes even before harvest. These results in a reduction of the number of lateral crowns being produced and in their growth vigour, also drastically reducing the marketable fruit yield in the next growing season (Maas 1998). According to the cited author, a marketable yield in the varieties that are moderately or very susceptible to $D$. earliana can be reduced by 34 and $57 \%$, respectively. Studies conducted by Mutisya et al. (2005a) on the susceptible cultivars 'Kent', 'Jewel' and 'Blomidon' had decreases in marketable yield of 25, 23 and $21 \%$, respectively. This was a result of the reduction in the number of lateral crowns produced by the infected plants. There was no effect of the severity of plant infection on the number of inflorescences per crown or fruits per inflorescence, nor on the average berry weight (Mutisya et al. 2005a, b). Heavily infected plants are also very sensitive to low (freezing) and high temperatures and drought resulting in high mortality (Maas 1998).

In our study, relatively low susceptibility to $D$. earliana was shown by the $\mathrm{F}_{1}$ hybrids derived from the varieties 'San Andreas', 'Figaro', 'Palomar' and 'Granda'. All of these genotypes had statistically significant, negative GCA effects for at least one season of observations and for the average score of the severity of plant infection by this pathogen over three years. These cultivars can therefore be widely used in breeding programmes aimed at developing new varieties resistant or low susceptible to the leaf scorch. No GCA $\times$ years interaction for these varieties is an additional advantage since it allows us to expect that their progeny will exhibit high stability in terms of resistance to this disease. For the crossing 
combinations of 'San Andreas' and 'Palomar', with statistically significant negative GCA effects for plant infection by $D$. earliana, significantly negative SCA effects were also estimated, and one should therefore expect the productivity of the derived hybrids to be significantly higher than what would appear from the sum of the GCA effects for their parental forms.

Although the severity of leaf infection by $S$. macularis of the tested strawberry seedlings was low, it varied and was, on average, 0.02, 0.65 and 0.65 in 2011, 2012 and 2013, respectively. Lowest powdery mildew pressures were observed in 2011 with the hydrids examined. At the same time, many genotypes $\times$ years interactions were found within the studied gene pool. This illustrates that weather conditions in a given growing season have a strong influence on the severity of infection with the powdery mildew of strawberry. Research shows that mycelia develop and survive in green tissue under all conditions, and sporulate at $5-30{ }^{\circ} \mathrm{C}$ (Miller et al. 2003). The optimal germination, growth of $S$. macularis conidia, and infection occurs at $15-25^{\circ} \mathrm{C}$ and humidity at 75-98 \% (Amsalem et al. 2006, Santos et al. 2003). Under such conditions, the first disease symptoms will appear 4 days after infection. Then, on the lower leaf surface, white patches of mycelium develop, which enlarge and coalesce to cover the entire lower surface (Maas 1998). The leaf edges roll upward, exposing the white, powdery fungal growth. Leaf petioles, flower trusses, flowers, and fruit may also be affected by this pathogen. Severe foliar infection reduces photosynthesis (Maas 1998), which weakens plant growth and reduces fruit yield (Bielenin et al. 1998, Santos et al. 2003). Therefore, according to Nelson et al. (1995), strawberry crop losses due to powdery mildew can be as high as $60 \%$.

Our three-year study showed the absence of any symptoms of infection by $S$. macularis of plants of the 'Portola' $\times$ 'Elianny' hybrids. However, the analysis of general combining ability for both these parental forms showed that only cultivar 'Portola' had the GCA effect for this trait with a statistically proven negative value (indicating low susceptibility to $S$. macularis), whereas the estimated GCA effect for 'Elianny' was significantly positive. This means that of these two cultivars only 'Portola' should be used in breeding as a donor of resistance or low susceptibility to powdery mildew. Despite the above, the genetic interaction of these two parental genotypes determines low susceptibility of the hybrids to the powdery mildew, as indicated by the significantly negative value of the SCA effect. From the descriptions of the two cultivars, available in the literature, it is known that both 'Portola' (Lewers 2012) and 'Elianny' (Masny and Żurawicz 2010) are considered to be moderately susceptible to the powdery mildew of strawberry. Among the evaluated cultivars, significantly negative values of GCA effects, and therefore high usefulness for breeding aimed at obtaining varieties low susceptible to powdery mildew, were also shown by 'Diamante', 'Charlotte', 'Monterey' and 'Salsa'.

\section{Conclusions}

Resistance/low susceptibility of strawberry plants to diseases of leaves is determined by both additive and non-additive genetic effects. In the inheritance of resistance/low susceptibility to the leaf spot and the powdery mildew of strawberry, non-additive effects are critical.

The assessed cultivars have different usefulness as potential parental forms for breeding new varieties with higher resistance to fungal diseases of leaves. The most useful for breeding varieties resistant/low susceptible to the leaf spot are: 'Diamante', 'San Andreas', 'Figaro', 'Salsa', 'Granda' and 'Camarosa'; to the leaf scorch 'Figaro', 'San Andreas', 'Palomar', 'Granda' and 'Salsa'; and to the powdery mildew of strawberry: 'Diamante', 'Salsa', 'Portola', 'Charlotte' and 'Monterey'. The least useful for resistance breeding are 'Aromas' and 'Elianny' because of their ability to pass on to their progeny high susceptibility to $S$. macularis, and in the case of 'Elianny' - also to $M$. fragariae.

High usefulness for resistance breeding of new varieties was illustrated by the combination 'Aromas' $\times$ 'Elianny', which has significantly negative SCA effects for the susceptibility of plants to leaf spot and leaf scorch, providing evidence of an interaction of the two parental genotypes in the creation of varieties that are resistant/low susceptible to these diseases.

Acknowledgments We thank Dr. David Percival, Department of Environmental Sciences, Dalhousie University, Truro, NS Canada, for comprehensive revision of the manuscript. This study was funded by the Polish Ministry of Agriculture and 
Rural Development ("Basic research for the biological progress"-Grant 106 "Genetic and biometric analysis of the strawberry parental forms for obtaining genotypes with high fruit quality and productive value of plants").

Open Access This article is distributed under the terms of the Creative Commons Attribution 4.0 International License (http:// creativecommons.org/licenses/by/4.0/), which permits unrestricted use, distribution, and reproduction in any medium, provided you give appropriate credit to the original author(s) and the source, provide a link to the Creative Commons license, and indicate if changes were made.

\section{References}

Amsalem L, Freeman S, Rav-David D, Nitzani Y, Sztejnberg A, Pertot I, Elad Y (2006) Effect of climatic factors on powdery mildew caused by Sphaerotheca macularis f. sp. fragariae on strawberry. Eur J Plant Pathol 114:283-292. doi:10.1007/s10658-005-5804-6

Averre CW, Jones RK, Milholland RD (2002) Strawberry diseases and their control. In: Creswell TC (reformatted) Plant Pathology Extension. College of Agriculture and Life Sciences-North Carolina State University. www.ces. ncsu.edu/depts/pp/notes/oldnotes/fd5.htm. Accessed: 09 Apr 2014

Baker RJ (1978) Issues in diallel analysis. Crop Sci 18:533-536

Bestfleisch M, Möhring J, Hanke MV, Peil A, Flachowsky H (2014) A diallel crossing approach aimed on selection for ripening time and yield in breeding of new strawberry (Fragaria $\times$ ananassa Duch.) cultivars. Plant Breed 133:115-120

Bielenin A, Cieślińska M, Łabanowska BH (1998) Atlas chorób i szkodników truskawki. Instytut Sadownictwa i Kwiaciarstwa, Skierniewice

Carisse O, Bourgeois G, Duthie JA (2000) Influence of temperature and leaf wetness duration on infection of strawberry leaves by Mycosphaerella fragariae. Phytopathology 90:1120-1125

Daubeny HA (1961) Powdery mildew resistance in strawberry progenies. Can J Plant Sci 41:239-243

Davik J, Honne BI (2005) Genetic variance and breeding values for resistance to a wind-borne disease [Sphaerotheca macularis (Wallr. Ex Fr.)] in strawberry (Fragaria $\times$ ananassa Duch.) estimated by exploring mixed and spatial models and pedigree information. Theor Appl Genet 111:256-264

Dhanvantari BN (1967) The leaf scorch disease of strawberry (Diplocarpon earliana) and the nature of resistance to it. Can J Bot 45:1525-1543. doi:10.1139/b67-157

Dossett M, Lee J, Finn CE (2008) Genetics and breeding inheritance of phenological, vegetative and fruit chemistry traits in black raspberry. J Am Soc Hortic Sci 133:408417

Faedi W, Baruzzi G, Lucchi P, Sbrighi P (2009) Monografia di cultivar di Fragola (Strawberry Cultivar Monography). In: VII Convegno Nazionale "La Fragola: Presente e Futuro",
Marsala, Italy, 25-30 Mar. 2009. Regione Siciliana Assessorato Agricoltura e Foreste, Roma

FAOSTAT (2014) http://faostat.fao.org/site/567/default. aspx\#ancor. Accessed 11 Mar 2014

Finn CE (1999) Strawberry. In: Okie WR (ed) Register of New Fruit and Nut Varieties-List 39. HortScience 34:197-201

Fort SB, Shaw DV (2000) Genetic analysis of strawberry root system traits in fumigated and nonfumigated soils. I. Inheritance patterns of strawberry root system characteristics. J Am Soc Hortic Sci 125:318-323

Garretsen F, Keuls M (1978) A general method for the analysis of genetic variation in complete and incomplete diallels and North Carolina II (NC II) designs. Part II. Procedures and general formulas for the fixed model. Euphytica 27:49-68

Giménez G, Ballington JR (2002) Inheritance of resistance to Colletotrichum acutatum Simmonds on runners of garden strawberry and its backcrosses. HortScience 37:686-690

Griffing B (1956a) A generalised treatments of diallel crosses in quantitative inheritance. Heredity 10:31-50

Griffing B (1956b) Concept of general and specific combining ability in relation to diallel crossing systems. Austral J Biol Sci 9:463-493

Howard CM, Overman AJ, Price JF, Albregts EE (1985) Diseases, nematodes, mites, and insects affecting strawberries in Florida. Bulletin 857. Agricultural Experiment Stations, Institute of Food and Agricultural Sciences, University of Florida, Gainesville, pp 41

Hsu CS, Watkins R, Bolton AT, Spangelo LPS (1969) Inheritance of resistance to powdery mildew in the cultivated strawberry. Can J Gen Cytol 11:426-438

Kupczak K (2013) Odmiany truskawki. Plantpress, Kraków, p 109

Lewers KS (2010) Strawberry. In: Clark JR, Finn CE (eds) Register of new fruit and nut varieties-List 45. HortScience 45:748-752

Lewers KS (2012) Strawberry. In: Finn CE, Clark JR (eds) Register of new fruit and nut varieties-List 46. HortScience 47:556-559

Maas JL (1998) Compedium of Strawberry Diseases. American Phytopathological Society Press, St. Paul, p 98

Maas JL (2014) Strawberry diseases and pests-progress and problems. Acta Hortic 1049:133-142

MacLachlan JB (1978) Data on the inheritance of resistance to powdery mildew in the cultivated strawberry. Sci Hortic 8:43-49

Masny A, Żurawicz E (2009) Yielding of new dessert strawberry cultivars and their susceptibility to fungal diseases in Poland. J Fruit Ornam Plant Res 17:191-202

Masny A, Żurawicz E (2010) Productive value of new foreign strawberry cultivars evaluated in 2007-2010. J Fruit Ornam Plant Res 18:273-282

Masny A, Żurawicz E (2013) Uprawa truskawek z uwzględnieniem zasad integrowanej ochrony. Plantpress, Kraków, p 180

McNicoll RJ, Gooding HJ (1979) Assessment of strawberry clones and seedlings for resistance to Sphaerotheca macularis. Hortic Res 19:35-41

Miller TC, Gubler WD, Geng S, Rizzo DM (2003) Effects of temperature and water vapor pressure on conidial 
germination and lesion expansion of Sphaerotheca macularis f. sp. fragariae. Plant Dis 87:484-492

Möhring J, Piepho HP (2009) Comparison of weighting in twostage analyses of series of experiments. Crop Sci 49:1977-1988

Muszyński S, Tomaszewski M, Mądry W, Sowa A, Zimny J (2000) Genetyka dla rolników. Część III. Podstawy matematyczne genetyki populacji. Fundacja "Rozwój SGGW", Warszawa, pp 118-178

Mutisya JM, Sullivan JA, Sutton JC, Zheng J, Couling S (2005a) Influence of leaf scorch on vegetative growth and yield of three strawberry (Fragaria $\times$ ananassa Duch.) cultivars with differing levels of resistance. Can J Plant Sci 85:679-686

Mutisya JM, Sullivan JA, Couling S, Sutton JC, Zheng J (2005b) Leaf scorch epidemics reduce vegetative growth and fruit yield of 'Kent' strawberry. HortScience 40:76-79

Nelson MD, Gubler WD, Shaw DV (1995) Inheritance of powdery mildew resistance in greenhouse-grown versus field-grown California strawberry progenies. Phytopathology $85: 421-424$
Santos B, Barrau C, Romero F (2003) Strawberry fungal diseases. Food Agric Environ 1:129-132. www.world-food. net

SAS Institute (2000) SAS language and procedure: usage. Version 8, 1st edn. SAS Institution, Cary

Simpson DW (1987) The inheritance of mildew resistance in everbearing and day-neutral strawberry seedlings. J Hortic Sci 62:329-334

Simpson DW (2014) Strawberry breeding and genetics research in North West Europe. Acta Hortic 1049:107-111

Vieira RA, Scapim CA, Moterle LM, Tessmann DJ, Conrado TV, Amaral AT Jr (2009) Diallel analysis of leaf disease resistance in inbred Brazilian popcorn cultivars. Genet Mol Res 8:1427-1436

Zhang Y, Kang MS, Lamkey KR (2005) DIALLEL-SAS05: a comprehensive program for Griffing's and Gardner-Eberhart analyses. Agron J 97:1097-1106

Zheng J, Sutton JC (1994) Inoculum concentration, leaf age, wetness duration, and temperature in relation to infection of strawberry leaves by Diplocarpon earlianum. Can J Plant Pathol 16:177-186 